\title{
A novel approach to model exposure of coastal-marine ecosystems to riverine flood plumes based on remote sensing techniques
}

Jorge G. Álvarez-Romero ${ }^{\mathrm{a}, \mathrm{b}^{*}}$, Michelle Devlin ${ }^{\mathrm{b}}$, Eduardo Teixeira da Silva ${ }^{\mathrm{b}}$, Caroline Petus ${ }^{\mathrm{b}}$, Natalie C. Ban ${ }^{\mathrm{a}}$, Robert L. Pressey ${ }^{a}$, Johnathan Kool ${ }^{a, \#}$, Jason Roberts ${ }^{c}$, Sergio Cerdeira-Estrada ${ }^{d}$, Amelia S. Wenger ${ }^{a, b}$, Jon Brodie ${ }^{b}$

\footnotetext{
${ }^{a}$ Australian Research Council Centre of Excellence for Coral Reef Studies, James Cook University, Townsville, QLD 4811, Australia

${ }^{b}$ Centre for Tropical Water and Aquatic Ecosystem Research, Catchment to Reef Research Group, James Cook University, Townsville, QLD 4811, Australia

c Duke University Marine Lab, Marine Geospatial Ecology Lab, 135 Duke Marine Lab Rd, Beaufort, NC 28516, USA

${ }^{d}$ Comisión Nacional para el Conocimiento y Uso de la Biodiversidad, Av. Liga Periférico-Insurgentes Sur 4903, Parques del Pedregal, 14010, México, D.F., México

\#Current address: Geoscience Australia, Environmental Geoscience Division, Coastal, Marine and Climate Change, GPO Box 378 Canberra ACT 2601 Australia
}

* Corresponding author: jorge.alvarez.romero@gmail.com

Citation: Álvarez-Romero, J.G., Devlin, M., Teixeira da Silva, E., Petus, C., Ban, N.C., Pressey, R.L., Kool, J., Roberts, J.J., Cerdeira-Estrada, S., Wenger, A.S., Brodie, J., 2013. A novel approach to model exposure of coastal-marine ecosystems to riverine flood plumes based on remote sensing techniques. Journal of Environmental Management 119, 194-207. http://dx.doi.org/10.1016/i.jenvman.2013.01.036

\section{Highlights}

- Classification of true-color satellite images can be used to map river plumes

- This method is also useful to qualitatively assess dispersal of river-borne pollutants

- Our results indicate large spatial-temporal variation in exposure to pollutants

- Our model can be applied to monitor exposure of marine ecosystems to plumes

- Combined with data on pollutant sources, our model can guide catchment management

\begin{abstract}
Increased loads of land-based pollutants are a major threat to coastal-marine ecosystems. Identifying the affected marine areas and the scale of influence on marine ecosystems is critical to assess the ecological impacts of degraded water quality and to inform planning for catchment management and marine conservation. Studies using remotely sensed data have contributed to our understanding of the occurrence and influence of river plumes, and to our ability to assess exposure of marine ecosystems to land-based pollutants. However, refinement of plume modeling techniques is required to improve risk assessments. We developed a novel approach to model exposure of coastal-marine ecosystems to landbased pollutants. We used supervised classification of MODIS-Aqua true-color satellite imagery to map the extent of plumes and to qualitatively assess the dispersal of pollutants in plumes. We used the Great Barrier Reef (GBR), the world's largest coral reef system, to test our approach. We combined frequency of plume occurrence with spatially distributed loads (based on a cost-distance function) to create maps of exposure to suspended sediment and dissolved inorganic nitrogen. We then compared annual exposure maps (2007-2011) to assess inter-annual variability in the exposure of coral reefs and seagrass beds to these pollutants. Our findings indicate that classification of true-color satellite images is useful to map plumes and to qualitatively assess exposure to land-based pollutants. This approach should be considered complementary to remote sensing methods based on ocean color products used to characterize surface water in plumes. Observed inter-annual variation in exposure of ecosystems to pollutants stresses the need to incorporate this temporal component into plume exposure/risk models. Our study contributes to our understanding of plume spatial-temporal dynamics of the GBR and offers a method that can improve plume exposure models. Our method can also be applied to monitor exposure of coastal-marine ecosystems to plumes and explore their ecological influences.
\end{abstract}

Keywords: marine spatial planning, river plume, flood plume, land-based pollution, water quality, marine conservation 


\section{Introduction}

Land-based pollution poses a major threat to marine ecosystems globally and is projected to increase with the expansion and intensification of agriculture, grazing, and urbanization (Butchart et al., 2010; CBD, 2006; Halpern et al., 2008; MEA, 2005). Increasing loads of land-based pollutants (e.g., nutrients, sediment, pesticides) associated with land use change are causing major ecological impacts, potentially interacting with other stressors (e.g., overfishing, increased ocean temperature, ocean acidification, sea level rise). Improving coastal-marine water quality is therefore a global priority (UNEP, 2012). Nutrient runoff from intensive use of fertilizers in agriculture can cause severe eutrophication, toxic phytoplankton blooms, and hypoxia in coastal and marine ecosystems (Cloern, 1996; Diaz and Rosenberg, 2008; Gabric and Bell, 1993; Howarth, 2008). Nutrient enrichment of coastal waters has also been related to increased risk of coral bleaching (Wooldridge, 2009) and outbreaks of the reef-destroying crown-of-thorns starfish (COTS) (Brodie et al., 2005; Fabricius et al., 2010). Globally, land use change associated with agriculture, forestry, and urbanization have led to significant soil loss, resulting in increased sediment loads and turbidity of coastal waters (Croke and Hairsine, 2006; Thrush et al., 2004; Walling, 2006); in turn, these have been related to reduced coral recruitment (Hutchings et al., 2005), increased seagrass mortality (Cabaco et al., 2008), and declines in invertebrate densities (Reid et al., 2011). Pesticides are a major concern, particularly for sites adjacent to coastal catchments with intensive agriculture or forestry plantations, and have been related to dieback in mangroves, as well as reduced photosynthesis and expulsion of the symbiotic algae (bleaching) from corals (Duke et al., 2005; Haynes et al., 2007; Hutchings et al., 2005).

Dispersal of land-based pollutants has been traced to offshore waters, sometimes hundreds of kilometers distant from river mouths (Beman et al., 2005; Brodie et al., 2010; Devlin and Schaffelke, 2009), highlighting the need to consider such threats in marine conservation planning. The ecological impacts of land-based pollutants vary with the magnitude and extent of riverine influence, but also with the coastal-marine ecosystems being affected (Halpern et al., 2007; Halpern et al., 2008), and the frequency and duration of river- i.e., masses of turbid freshwater discharged by rivers and extending into the sea - (McKenzie and Unsworth plumes, 2011). Thus considering land-based threats is of utmost importance when planning for coastal-marine conservation and catchment management (Alvarez-Romero et al., 2011). Ignoring the potential impacts of land-based threats can reduce the effectiveness of marine conservation areas (Stoms et al., 2005; Wilson et al., 2005), especially when these threats are extensive (Brodie et al., 2012b; Halpern et al., 2009). Furthermore, land-based pollution impacts not only marine biodiversity but also human livelihoods by compromising marine ecosystem services, such as food provisioning, recreation, and protection against coastal hazards (Lubchenco et al., 2003; Worm et al., 2006).

Identifying marine areas and ecosystems affected by land-based impacts is crucial if management is to address those impacts. Mapping river plumes - their extent and surface water characteristics - is key to understanding the flow of landbased pollutants into marine systems (Devlin et al., 2011). Several approaches have been developed to map river plumes, but improvements are possible and desirable. A common approach has been visual delineation of plumes based on aerial photography and satellite imagery (Devlin and Schaffelke, 2009; Devlin et al., 2011). Key limitations of visual interpretation are the need for considerable experience and inevitable human error. This method is also time-consuming, thus limiting the number of images that can be processed. Some notable advances have been made in automating the process of identifying plumes with ocean-color products derived from satellite images. This approach has been used successfully to map the freshwater extent of plumes (Schroeder et al., 2012) and to monitor variations in surface water parameters (Brando et al., 2010). However, to date these methods are limited because estimated parameters (e.g., chlorophyll, suspended sediment) can be associated with processes other than river plumes. In addition, these methods generally perform poorly under atmospheric and water conditions such as moderate cloud cover and sun glint and high turbidity characteristic of the initial phases of plumes. Hydrodynamic models have also been used, in combination with estimated pollutant loads discharged by rivers, to estimate the dispersal of pollutants and hence to assess exposure of marine ecosystems to pollutants (e.g., Cherubin et al., 2008). However, this approach generally requires significant expertise and computational resources and, in most cases, has not been validated against in situ data because of time and resources required for studies covering large regions. Because of the limitations of existing methods for mapping river plumes, we explore here a novel approach that overcomes some of these limitations.

The purpose of our study was to develop a new method to assess exposure of coastal-marine ecosystems to land-based pollutants. Our approach, based on the automated classification of true-color satellite imagery, offers a way of mapping 
plumes under moderate cloud cover and with sun glint, as well as in highly turbid waters where the performance of other remote sensing methods is limited. More specifically, we aim to improve existing plume mapping and estimating exposure to river-borne pollutants in two ways: (1) by developing a relatively simple method to map the extent of land-based pollutants and qualitatively assess their dispersal; and (2) by assessing spatial-temporal variability in the exposure of marine ecosystems (coral reefs and seagrass beds) to plumes, necessary for estimating potential impacts. Our study contributes to our understanding of the spatial-temporal dynamics of plumes in the Great Barrier Reef (GBR), Australia, but describes a method that is much more widely applicable. We discuss the application of our method to monitor exposure of marine ecosystems to plumes and to study ecological responses to land-based pollutants.

\section{Material and methods}

\subsection{Study region}

Our study focuses on the GBR, the world's largest coral reef system, located in the Coral Sea, off the coast of Queensland in northeast Australia, and a World Heritage Site since 1981. The GBR is globally recognized for its outstanding ecological, cultural and socioeconomic values (GBRMPA, 2009) and since 1975 a large part of the reef is protected by the Great Barrier Reef Marine Park (GBRMP). The GBRMP includes around 2,900 reefs and 940 islands and cays, covering almost $345,000 \mathrm{~km}^{2}$. The sheer extent of the park helps to limit the impact of human use, such as fishing and tourism (Day, 2011). The rezoning of the GBRMP vastly increased the area under strict protection (i.e., no-take areas) from $4.5 \%$ to $>33 \%$ (Fernandes et al., 2005), with documented benefits for marine biodiversity and fisheries (McCook et al., 2010). However, threats originating from land-based activities (e.g., coastal development and decreased water quality associated with agriculture and grazing in coastal catchments), and from global climate change (e.g., increased water temperature and ocean acidification) are major concerns (Brodie et al., 2012b; GBRMPA, 2009). Since the arrival of Europeans in Australia, loads of suspended sediments delivered to the GBR have increased drastically following extensive land clearing for grazing, agriculture and coastal development (Joo et al., 2012; Kroon et al., 2012). Similarly, fertilized cropping has significantly increased the loads of nutrients (particularly dissolved inorganic nitrogen and phosphorus), thus resulting in eutrophication of estuarine and marine environments (Brodie et al., 2011; Brodie et al., 2012b). Pesticides washed from agricultural lands add to the load of land-based pollutants delivered into the sea (Kennedy et al., 2012; Lewis et al., 2009). Most of the pollutants are delivered during the wet season and in particular during peak-flow periods, when large plumes can be identified along the coast (Devlin and Brodie, 2005), occasionally reaching offshore reefs (Devlin et al., 2012b; Schroeder et al., 2012).

We focus our 5-year study (2007-2011) on four of the six Natural Resource Management regions (hereafter NRMs) of the GBR: Wet Tropics, Burdekin, Mackay-Whitsundays, and Fitzroy (Figure 1). The Cape York and Mary-Burnett NRMs were excluded from our study because information on estimated annual loads was not available or incomplete. The four selected NRMs illustrate a range of land use and landscape characteristics (e.g., climate, soils, topography) that result in different patterns of delivery of pollutants by major rivers across the GBR (Brodie et al., 2009; Kroon et al., 2012). Differences in flow are reflected in the spatial and temporal distribution and composition of river plumes observed along the GBR coast (Devlin et al., 2011; Devlin et al., 2001). Along this wide latitudinal range $\left(10^{\circ} 41^{\prime} 20^{\prime \prime} \mathrm{S}\right.$ to $\left.24^{\circ} 30^{\prime} 00^{\prime \prime} \mathrm{S}\right)$ are also differences in the distribution of marine ecosystems (e.g., coral reefs in the north are closer to the coast), which means that some of these ecosystems are more likely to be affected by plumes of comparable magnitude. These characteristics make the GBR an ideal area to study plume dynamics across large areas and to illustrate the application of our plume exposure model for regional planning. 


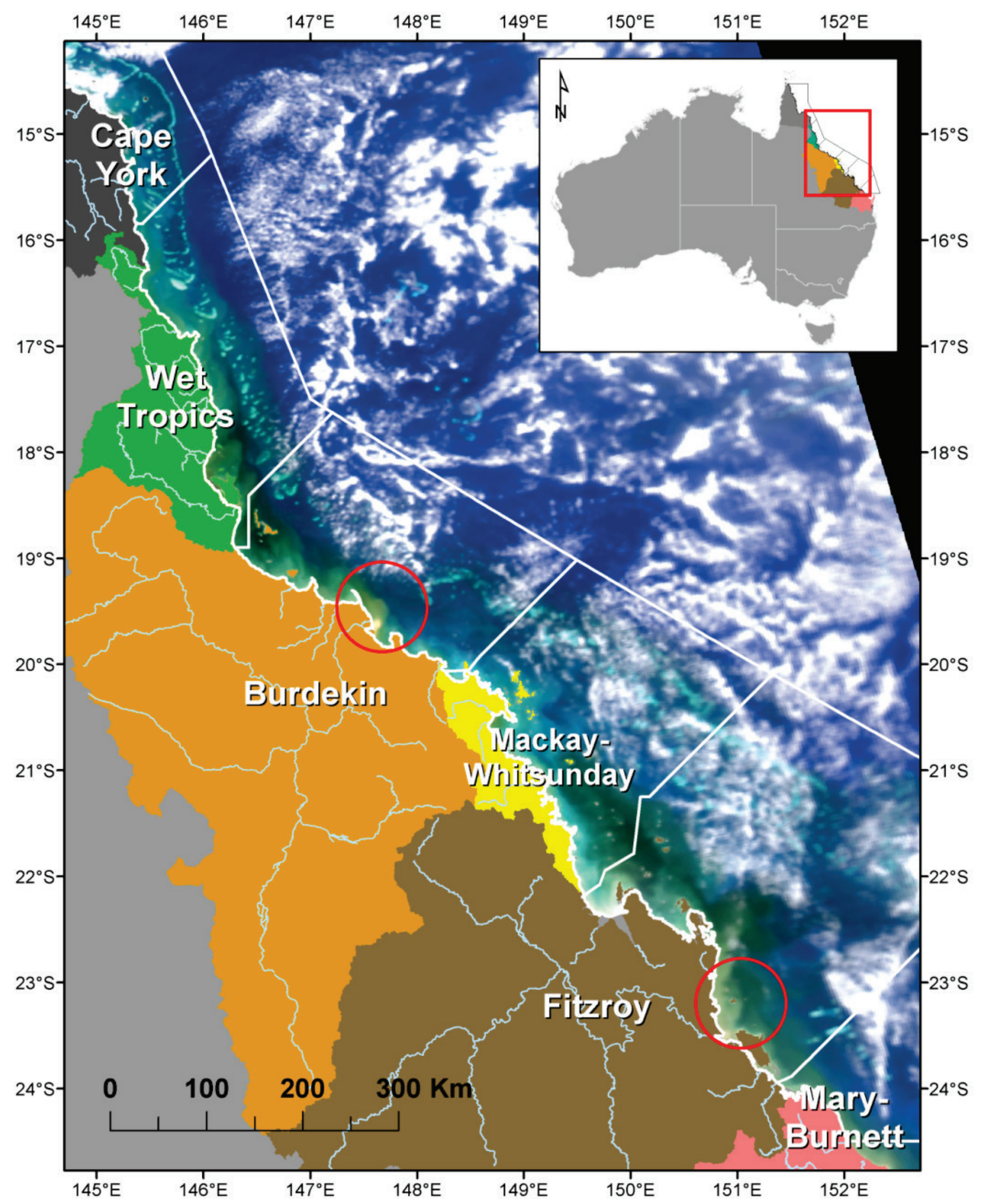

Figure 1. MODIS-Aqua satellite image (from NASA Ocean Color online catalog) illustrating river flood plumes along the coast of the Great Barrier Reef Marine Park, Australia on January 25, 2011. The presence of high suspended sediment areas - identifiable as brown areas (red circles) close to river mouths - is more evident for the two largest rivers, the Burdekin and Fitzroy. The six coastal NRMs of the GBR catchment are shown in different colors. These NRM regions extend seaward and are limited by the GBR Marine Park boundary (delineated by white lines) thus providing management areas that align with catchment practices. 


\subsection{Modeling exposure to plumes}

Our exposure model builds on previous models developed for the GBR (i.e., Devlin et al., 2012b; Maughan and Brodie, 2009), but includes several improvements. We selected two pollutants for in-depth examination because of their known impacts on the GBR: total suspended sediment (TSS) and dissolved inorganic nitrogen (DIN) (Brodie et al., 2012b; Fabricius, 2011). Both TSS and DIN are commonly measured in water quality monitoring programs. In the GBR, loads of these pollutants vary significantly between marine areas adjacent to NRMs in the GBR (Joo et al., 2012; Waterhouse et al., 2012). These pollutants also have different dispersal patterns and hence spatial patterns of exposure across the GBR (Devlin et al., 2001; Devlin and Brodie, 2005). Our analysis focused on the summer wet season (December to April inclusive) and, unlike previous studies limited to low cloud-cover days (Devlin et al., 2012b; Maughan and Brodie, 2009), used all available MODIS-Aqua satellite images over the GBR (usually 2 images per day). Restricting the analysis to summer months minimized problems associated with sunlight reflection on the ocean surface (i.e., in summer, the solar zenith angle is smallest and albedo problem is limited). It also minimized the occurrence of "false" plume areas associated with wind-driven re-suspension of sediments during the strong trade winds typical of the dry season (Larcombe et al., 1995; Orpin et al., 1999). Almost 2,100 images were available for the GBR region for the study years (2007-2011), but not all images contained data within the boundaries of our study area. The main output of our model was a qualitative map indicative of annual exposure of any given area within the GBR to TSS and DIN. The model was constructed in five steps (Figure 2), each of which is described in the sections that follow.
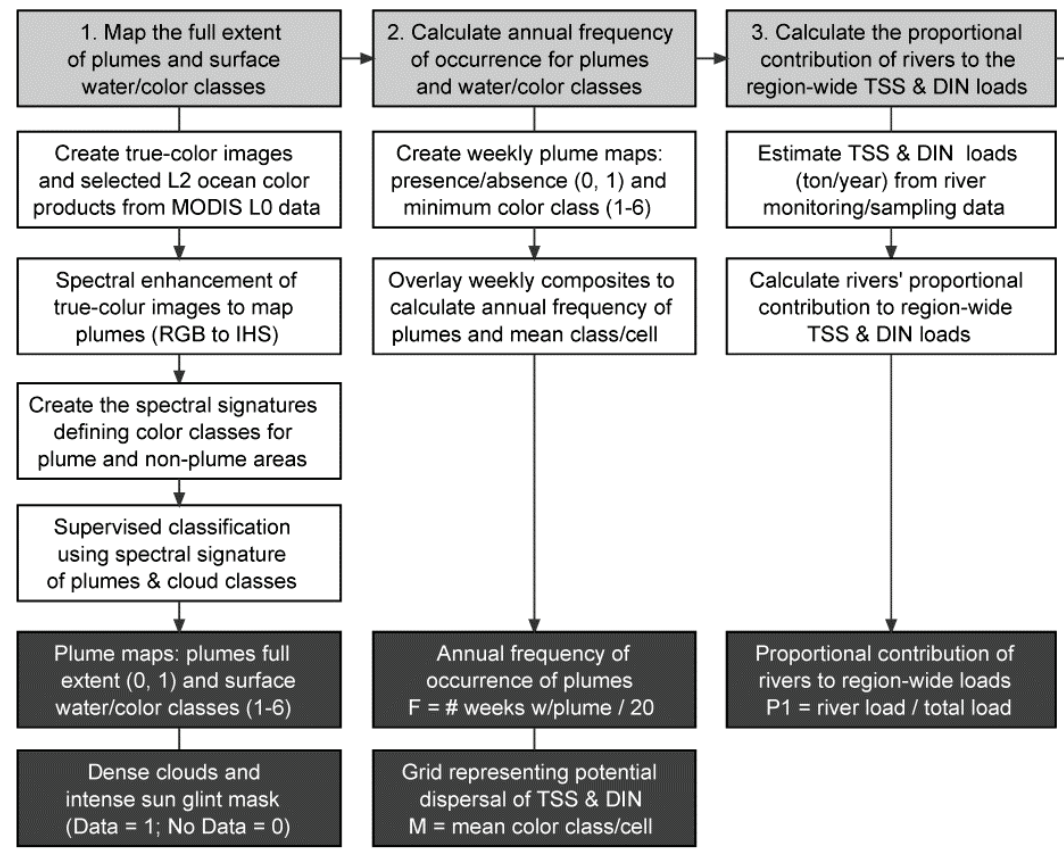
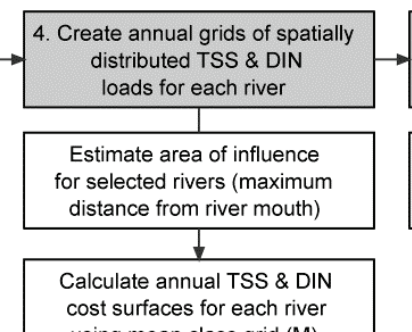

using mean class grid $(M)$

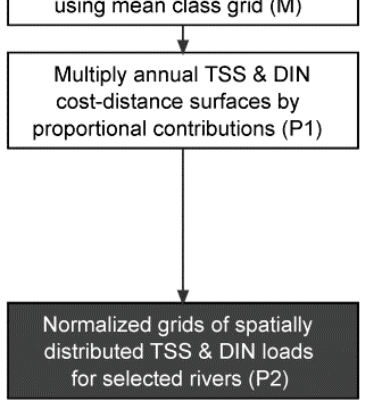

5. Calculate exposure by combining
the frequency and the spatially the frequency and the spatially
distributed DIN \& TSS grids distributed DIN \& TSS grids
Multiply annual plume frequency (F) by spatially distributed loads (P2) for TSS \& DIN

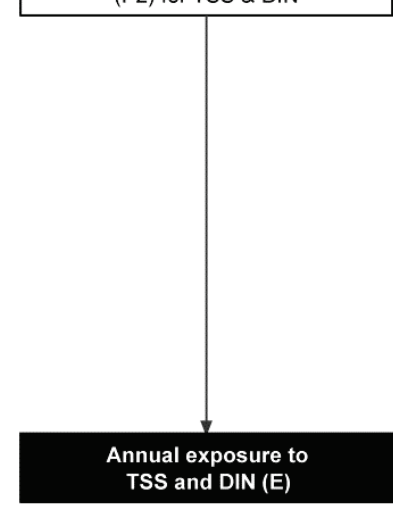

Figure 2. Summary of the process followed to build the plume exposure model. Different shadings represent steps (light gray), key analyses within steps (white), intermediate outputs (dark gray), and final output (black).

\subsubsection{Map the full extent of plumes and surface water/color classes}

The first step in modeling exposure is to identify (map) existing plumes, as well as clouds and sun glint, in each of the $\sim 2,100$ satellite images. This step includes mapping the different surface water masses observable within plumes (represented by color classes), which are later used to represent the dispersal of pollutants. It also includes the use of ocean-color products (described below) to define and characterize color classes, which in turn are used to describe a gradient in surface-water quality parameters. We mapped river plumes with four analyses. The L2 parameters were used to characterize the gradient described by mapped color classes described below.

First, we created the satellite products necessary for subsequent analyses. We used raw data (Level-0, hereafter L0) from the Moderate Resolution Imaging Spectroradiometer (MODIS) Aqua sensor (freely available from NASA's Ocean Color catalogue: oceancolor.gsfc.nasa.gov/cgi/browse.pl) to derive two types of products: (i) quasi-true color (hereafter true- 
color) RGB-143 images, resampled to $\sim 400 \mathrm{~m}$ using band 1 of MODIS ( $645 \mathrm{~nm}$ ) at $250 \mathrm{~m}$ resolution, band 4 (555 nm) and band $3(469 \mathrm{~nm})$ at $500 \mathrm{~m}$ resolution; and (ii) two ocean-color products (Level-2, hereafter L2 parameters): nLw667 and $\operatorname{adg}_{443}$ (Table 1). We derived the two L2 parameters using NASA's SeaWiFS Data Analysis System (SeaDAS v6.2, Baith et al., 2001) after correcting for atmospheric contaminations. The correction involved the combined near infrared to short wave infrared atmospheric correction scheme adapted to both clear and turbid waters, commonly found in the nearshore regions of the GBR (Wang and Shi, 2007). We used a modified script of the Marine Geospatial Ecology Tools (MGET, Roberts et al., 2010) to convert the swath-formatted L2 parameters into points, which we then used in ArcMap (ESRI, 2010) to explore the relationship between the L2 parameters and the mapped color classes (Supplementary Material).

Table 1. Selected L2 parameters derived from MODIS satellite imagery. The gradient in L2 parameters is considered to be indicative of variations in water quality within plumes (Devlin et al., 2012b), and thus was used to identify the plume boundary and to represent the potential dispersal of pollutants.

\begin{tabular}{|c|c|c|c|}
\hline L2 parameter & Description & Application in plume mapping & Algorithms \\
\hline nLW667 & $\begin{array}{l}\text { Normalized water-leaving } \\
\text { radiance at } 667 \mathrm{~nm}\end{array}$ & $\begin{array}{l}\text { Normalized water-leaving radiance at higher wavelengths } \\
\text { (555 } \mathrm{nm} \text { or } 667 \mathrm{~nm} \text { ) is sensitive to suspended sediment in } \\
\text { the water column and is correlated with plume location } \\
\text { (Salisbury et al., 2004; Thomas and Weatherbee, 2006). } \\
\text { We use this parameter as a proxy for TSS and to } \\
\text { approximate the dispersal of sediment within the plume. }\end{array}$ & $\begin{array}{l}\text { Defined as upwelling radiance just above the sea } \\
\text { surface, in the absence of an atmosphere, and } \\
\text { with the sun directly overhead (Gordon and } \\
\text { Wang, 1994). }\end{array}$ \\
\hline $\operatorname{adg}_{443}$ & $\begin{array}{l}\text { Colored dissolved organic } \\
\text { and detrital matter (CDOM } \\
+ \text { D) absorption coefficient } \\
\text { at } 443 \mathrm{~nm}\end{array}$ & $\begin{array}{l}\text { CDOM has been proposed as a proxy for salinity and thus } \\
\text { been used to estimate the maximum extent of river } \\
\text { plume influence (Schroeder et al., 2012). We use it to } \\
\text { estimate the dispersal of dissolved inorganic nitrogen } \\
\text { assuming conservative mixing. }\end{array}$ & $\begin{array}{l}\text { Derived using the quasi-analytical algorithm } \\
\text { (QAA) model (Lee et al., 2002), which estimates } \\
\text { absorption due to gelbstof and detrital material } \\
\text { at sensor wavelength of } 443 \mathrm{~nm} \text {. }\end{array}$ \\
\hline
\end{tabular}

Second, we prepared the true-color images for plume mapping. We spectrally enhanced the true-color images using Image Analysis for ArcGIS (ERDAS, 2010), which involved converting images from the Red-Green-Blue (RGB) to the Intensity-Hue-Saturation (IHS) color space. Images converted from RGB to IHS have been used to identify and track the movement of river plume fronts (Morichon et al., 2008). The same true-color images were used to map clouds and sun glint, but these were not enhanced for this purpose. Using RGB instead of IHS images for clouds and sun glint was more conservative because larger areas are identified as clouds/sun glint, which are in turn masked out to minimize classification errors.

Third, we defined color classes corresponding to plume and non-plume areas, as well as to dense clouds and sun glint, and created a spectral signature for each class. We did this using an image with large plumes occurring along the whole GBR coast (Figure 1) to ensure that color variations within plumes along the latitudinal gradient were incorporated into the spectral signature. The selected image included large areas with no plumes, varied atmospheric conditions (light to dense clouds, haze and sun glint), and sections with no data (not covered by satellite swath). To create the spectral signatures, we used the ArcMap Spatial Analyst (ESRI, 2010) isodata clustering tool to perform an unsupervised classification of the selected image. Unsupervised classification tries to find structure in unlabeled data (in our case to identify color classes for plumes and non-plume areas) through an iterative optimization clustering procedure (Ball and Hall, 1965). The resulting structure then allows characterization of the natural groupings of cells (i.e., pixels within an image) in multidimensional attribute space, in this case the IHS and RGB spaces, for plumes and clouds/sun glint, respectively. We assessed plume maps produced using different number of classes based on two criteria: how well the mapped classes identified the river plume boundary (we assessed the classified images against visually interpreted truecolor imagery); and whether the variation of selected L2 parameters among the color classes showed the expected gradient (as described by Devlin et al., 2012b; see section 3.1.1). For each classification, we plotted the mean value of the two L2 parameters for each color class (Supplementary Material). Due to reflectance similarities between land and very turbid plumes occurring in the mouth of the rivers, we classified the full image, without masking out land. This allowed us to map very turbid/high TSS plume areas commonly found near river mouths, which are frequently flagged incorrectly as land or very dense clouds (e.g., Devlin et al., 2012b; Okada et al., 2003; Schroeder et al., 2012). We selected the classification based on six color classes as the most appropriate for plume mapping. These classes represent a gradient in exposure to pollutants, from highest in class 1 to lowest in class 6, as explained below. 
Finally, we used supervised classification to map the full extent of plumes, as well as to create a mask representing dense clouds and intense sun glint. Supervised classification uses labeled training data (i.e., the color classes defined in the previous step) to create a spectral signature for each class, which is then used to classify all of the input imagery ( 2,100 images) into color classes (i.e., 6-class plumes, non-plume areas, and clouds/sun glint). We used the ArcMap Spatial Analyst maximum-likelihood classification tool (ESRI, 2010) to produce: (1) daily 6-class plume maps representing variations in L2 parameters (also used to identify the plume boundary) and (2) masks representing dense clouds and intense sun glint, used to eliminate areas with insufficient information to map plumes. We selected a number of images covering different years, regions and months to confirm the plume extent and overall congruence of our classified plume maps against plume maps produced using the method proposed by Devlin et al. (2012b), as well as to visually validate the clouds/sun glint masks.

\subsubsection{Calculate annual frequency of occurrence for plumes and color classes}

In the second step of the process (Figure 2), we used the mapped plumes to assess (on a cell-by-cell basis) how frequently they occurred, as well as to identify the most commonly observed color classes for each year. To do this, we created weekly composite images (using the daily 6-class plume maps) to minimize the amount of area without data per image due to masking of dense cloud cover, common during the wet season (Brodie et al., 2010), and intense sun glint. We used the minimum color-class value of each cell/week to ensure mapping the color class that represented the highest level of exposure to pollutants observed at any day during the corresponding week (i.e., assuming the color gradient represented a gradient in exposure to pollutants). We then overlaid weekly composites (i.e., presence/absence and minimum class value) to calculate: annual frequency of occurrence of plumes $(F)$, representing the proportion of weeks plumes were present in each cell during the wet season; and mean color class value across all weeks $(M)$, which was used to create a grid (i.e., a map in a raster data storage format, where each cell or pixel of the map is equal in size and has a numeric value) representing potential dispersal of pollutants (section 2.2.4).

\subsubsection{Calculate the proportional contribution of rivers to the region-wide TSS/DIN load}

In our third step (Figure 2), we used estimated TSS and DIN loads (calculated from measurements close to river mouths) to calculate the percentage of TSS and DIN delivered by each river in relation to the total TSS/DIN load from the catchments in all four NRMs. We used annual loads from seven major rivers draining into the four selected NRMs to calculate their proportional contribution to the total pollutant load. End-of-system loads were estimated based on flow and water quality sampling in selected gauging stations (Joo et al., 2012) for five monitoring periods (2007-2011) for TSS and DIN (Table 2). The proportional contributions were calculated by dividing the TSS and DIN annual loads of each river by the summed load for all rivers.

Table 2. Estimated annual end-of-system pollutant loads for major GBR catchment rivers in tons (DIN) and kilotons (TSS).

\begin{tabular}{ccccccc} 
River & & 2007 & 2008 & 2009 & 2010 & 2011 \\
\hline \multirow{2}{*}{ Barron } & DIN & 32 & 102 & 44 & 50 & 174 \\
\cline { 2 - 7 } & TSS & 30 & 397 & 163 & 174 & 239 \\
\hline \multirow{2}{*}{ Johnstone } & DIN & 518 & 409 & 487 & 339 & 731 \\
\cline { 2 - 7 } & TSS & 132 & 160 & 241 & 114 & 461 \\
\hline \multirow{2}{*}{ Tully } & DIN & 979 & 686 & 652 & 450 & 1,073 \\
\cline { 2 - 7 } & TSS & 116 & 88 & 113 & 70 & 232 \\
\hline \multirow{2}{*}{ Herbert } & DIN & 390 & 393 & 753 & 336 & 1,620 \\
\cline { 2 - 7 } & TSS & 337 & 220 & 1,888 & 336 & 1,344 \\
\hline \multirow{2}{*}{ Burdekin } & DIN & 1,815 & 2,646 & 2,324 & 1,036 & 2,588 \\
\cline { 2 - 7 } & TSS & 6,503 & 12,700 & 9,614 & 1,351 & 6,167 \\
\hline \multirow{2}{*}{ Pioneer } & DIN & 194 & 142 & 125 & 477 & 642 \\
\cline { 2 - 7 } & TSS & 156 & 255 & 111 & 374 & 819 \\
\hline \multirow{2}{*}{ Fitzroy } & DIN & 244 & 1,773 & 367 & 2,061 & 4,796 \\
\cline { 2 - 7 } & TSS & 320 & 4,751 & 404 & 3,564 & 8,665 \\
\hline \multirow{2}{*}{ TOTAL } & DIN & $\mathbf{4 , 1 7 2}$ & 6,151 & $\mathbf{4 , 7 5 2}$ & 4,749 & 11,624 \\
\cline { 2 - 7 } & TSS & $\mathbf{7 , 5 9 4}$ & 18,571 & 12,534 & 5,983 & 17,927 \\
\hline
\end{tabular}


Load estimates are based on measurements at gauge stations closest to river outlets. The figures underestimate loads because they do not include supply from coastal areas downstream of gauge stations, although the magnitude of the difference between estimated and total pollutant loads is unknown. Source: Queensland Department of Environment and Resource Management.

\subsubsection{Create annual grids of spatially distributed TSS and DIN loads for each river}

In the fourth step, we created grids representing the annual average distribution of TSS and DIN delivered by the seven major rivers in the study region. We created grids for each river by multiplying their proportional contribution to the region-wide TSS and DIN loads (section 2.2.3) with a cost-distance grid defining the maximum area of influence and the dispersal of pollutants in the sea (described below). We then summed the individual spatially distributed grids (one per river) to represent the full TSS and DIN load per cell; the overlap of two or more grids defined cells influenced by multiple rivers.

We used ArcMap Spatial Analyst (ESRI, 2010) to create the annual cost-distance grids for each river based on three inputs: source locations (points representing river mouths), a maximum distance (measured from river mouths), and a "cost" grid (representing how easily the pollutants spread in the ocean). We calculated the maximum distance for each river based on the volume of the largest flood event of the year (which was assumed to produce the largest plume) and the estimated extents of studied river plumes. A review on the extent of the Burdekin plume indicates that the maximum northward distance reached by the plume from the river mouth is $\sim 500 \mathrm{~km}$ for extreme-very large discharge events $(>12,000 \mathrm{GL})$ and $\sim 200 \mathrm{~km}$ for average (3,000 to 7,000 GL) events (Lewis et al., 2006). We analyzed daily hydrographs for each river (Supplementary Material) to identify flood events (defined as the sum of consecutive daily discharges exceeding the $95^{\text {th }}$ percentile mean flow for a 10-year period: 2002-2011). Values over and under the $95^{\text {th }}$ percentile marked the start and end of each flood event. The largest events were those with the largest summed flood volume.

We calculated the maximum distance for each river/year using a power function that approximates the relation between the known distance $(D)$ and volume $(V)$ of the largest discharges (i.e., $D=X^{0.6}$ ) of the Burdekin River. We adjusted the distance when the observed extent (i.e., distance to the border of our mapped plumes) was larger than the distance predicted by this power function (Table 3). We calculated the cost surface (a grid defining the "cost" per unit distance or impedance to move planimetrically through each cell) independently for TSS and for DIN. We did this using the grid representing the average color-class value for each cell, calculated from the weekly composites of 6-class plume maps. For TSS, a second polynomial function best fitted the observed relation between the six color classes and nIw667 (i.e., TSS proxy) and showed the expected gradient. For DIN we assumed conservative mixing (an approximation only) and thus used an inverse linear function that best fitted the relationship between color classes and adg 443 , a proxy for CDOM (CDOM has been used as proxy for salinity and thus to estimate area of riverine/plume influence; Schroeder et al., 2012). We normalized both DIN and TSS cost surfaces (Figure 3). The coastline and islands were assigned with 'No Data' values, hence effectively acting as barriers in the calculation of the cost-distance surface and consequently influenced the modeled dispersal of pollutants.

\subsubsection{Calculate exposure by combining the frequency and the spatially distributed DIN and TSS grids}

In the fifth step of the analytical process, to create the final maps of exposure $(E)$, we multiplied the annual frequency of plume occurrence grid $(F)$ by the grid representing the sum of spatially distributed TSS and DIN loads for all rivers $(P)$. We grouped exposure values in five categories of exposure (from very low to very high) to investigate spatial variation in exposure. 
Table 3. Volume of largest flood events and maximum distance of influence for major rivers. Flow data were obtained from Queensland Government flow program: http://watermonitoring.derm.qld.gov.au/host.htm. Distance values are estimates of the maximum linear distances $(\mathrm{km})$ from river mouths that plumes can reach (and transport pollutants) based on the relationship between discharge volume and observed extent of plumes. Distances in brackets are adjusted values based on observed extents of mapped plumes.

\begin{tabular}{ccccccc} 
River & & 2007 & 2008 & 2009 & 2010 & 2011 \\
\hline \multirow{2}{*}{ Barron } & Volume & 105 & 796 & 202 & 171 & 949 \\
& Distance & 16 & $50(65)$ & $24(75)$ & $20(75)$ & $53(106)$ \\
\hline \multirow{2}{*}{ Johnstone } & Volume & 370 & 470 & 800 & 208 & 547 \\
& Distance & $35(80)$ & $40(55)$ & $55(70)$ & $25(60)$ & $44(80)$ \\
\hline \multirow{2}{*}{ Tully } & Volume & 691 & 416 & 968 & 112 & 576 \\
& Distance & $51(80)$ & $37(70)$ & $62(95)$ & $17(75)$ & $45(115)$ \\
\hline \multirow{2}{*}{ Herbert } & Volume & 2,178 & 605 & 7,056 & 269 & 2,781 \\
& Distance & 101 & $47(80)$ & 204 & $29(90)$ & $117(130)$ \\
\hline \multirow{2}{*}{ Burdekin } & Volume & 6,260 & 14,849 & 22,443 & 1,401 & 9,495 \\
& Distance & 190 & 318 & 408 & $77(160)$ & $244(270)$ \\
\hline \multirow{2}{*}{ Pioneer } & Volume & 381 & 471 & 222 & 285 & 732 \\
& Distance & 35 & 40 & 26 & 30 & 52 \\
\multirow{2}{*}{ Fitzroy } & Volume & 371 & 5,410 & 865 & 7,088 & 27,036 \\
& Distance & $35(150)$ & 174 & $58(150)$ & $204(300)$ & 456 \\
\hline
\end{tabular}

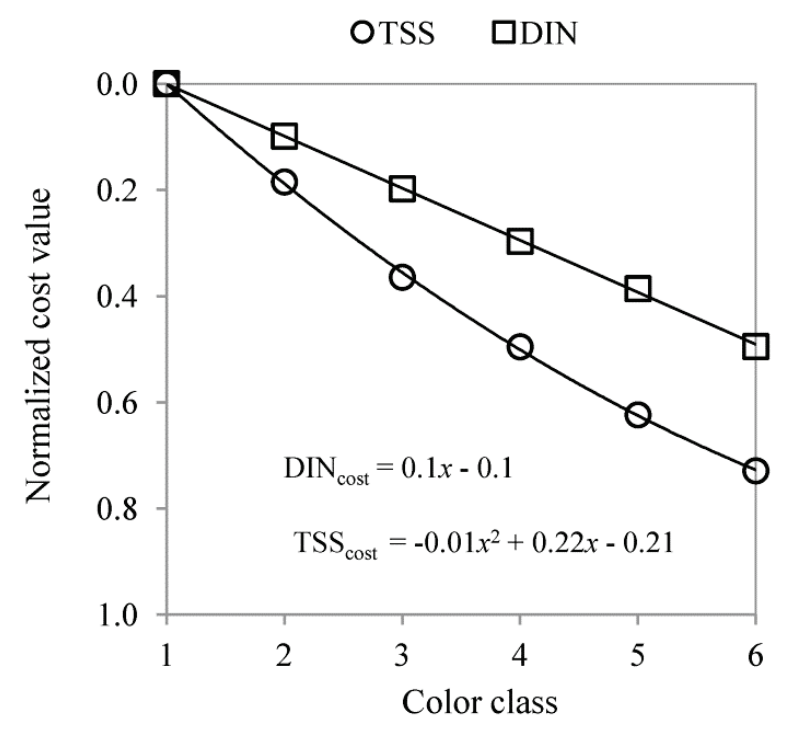

Figure 3. Functions used to calculate cost surfaces for total suspended sediment (TSS) and dissolved inorganic nitrogen (DIN). These functions represent the best relationships obtained between color classes and $\mathrm{LLW}_{667}$ and adg a $_{43}$ (section 2.2.2). The line corresponding to TSS depicts the modeled decay function used to represent dispersal of sediments. The line corresponding to DIN indicates the estimated linear decay (assuming conservative mixing) of dissolved pollutants, in this case based on the observed gradient of $\operatorname{adg}_{443}(\mathrm{CDOM}+\mathrm{D})$. In this case, the highest exposure class (1) has the lowest cost value and the lowest exposure class (6) the highest.

\subsection{Spatial and temporal variability in exposure of marine ecosystems to plumes}

Using the annual exposure maps, we quantified exposure to pollutants in two ways. First, we quantified the total area in each exposure class for TSS and DIN. Second, we calculated the area of coral reefs and seagrass beds affected by different exposure categories. We did this analysis for each year and plotted the variation in total area and affected areas of these ecosystems to analyze variation through time. We compared between years the total area and the affected area of the selected ecosystems under different exposure categories to understand inter-annual variability in exposure in relation to estimated loads. We also explored the relationship between the estimated maximum area covered by plumes and annual discharge. 


\section{Results}

\subsection{Modeling exposure}

\subsubsection{Plume mapping}

Color classes identified using our supervised classification method delineated the water masses and plume boundaries that were visually recognizable in the true-color images (Figure 4). The 6-class plumes showed the expected gradient in L2 parameters (Figure 5), and thus we considered the classes useful to qualitatively assess exposure to pollutants and to create exposure maps. Mapped plumes also provided enough detail to interpret the observed surface water masses. The first four color classes (Figure 4B) included the more turbid plume zone close to the coastline, characterized by high TSS and light-limiting conditions and very low salinity associated with the river mouth areas and the initial stages of plume formation. These four classes roughly match the primary water type (Figure 4C) described by Devlin et al. (2012b) and define the zone where most suspended sediments are deposited. The fifth class represented plume areas with moderately elevated TSS with sufficient light and excess nutrients to support elevated phytoplankton growth, similar to the secondary water type of Devlin et al. (2012b). The sixth color class included riverine influenced waters, generally characterized by lower values of colored dissolved organic and detrital matter (CDOM+D) than in previous classes, but still above ambient non-plume values. This is similar to the tertiary water type of Devlin et al. (2012b).

Our visual assessment of classified images indicated that using IHS images instead of RGB (not shown here) appreciably improved the correct delineation of the plume boundary and better discerned the very turbid brown water occurring near river mouths and the less turbid transition zones, as well as better resolving the different intensities or hues of green water found within plumes further away from the coast.
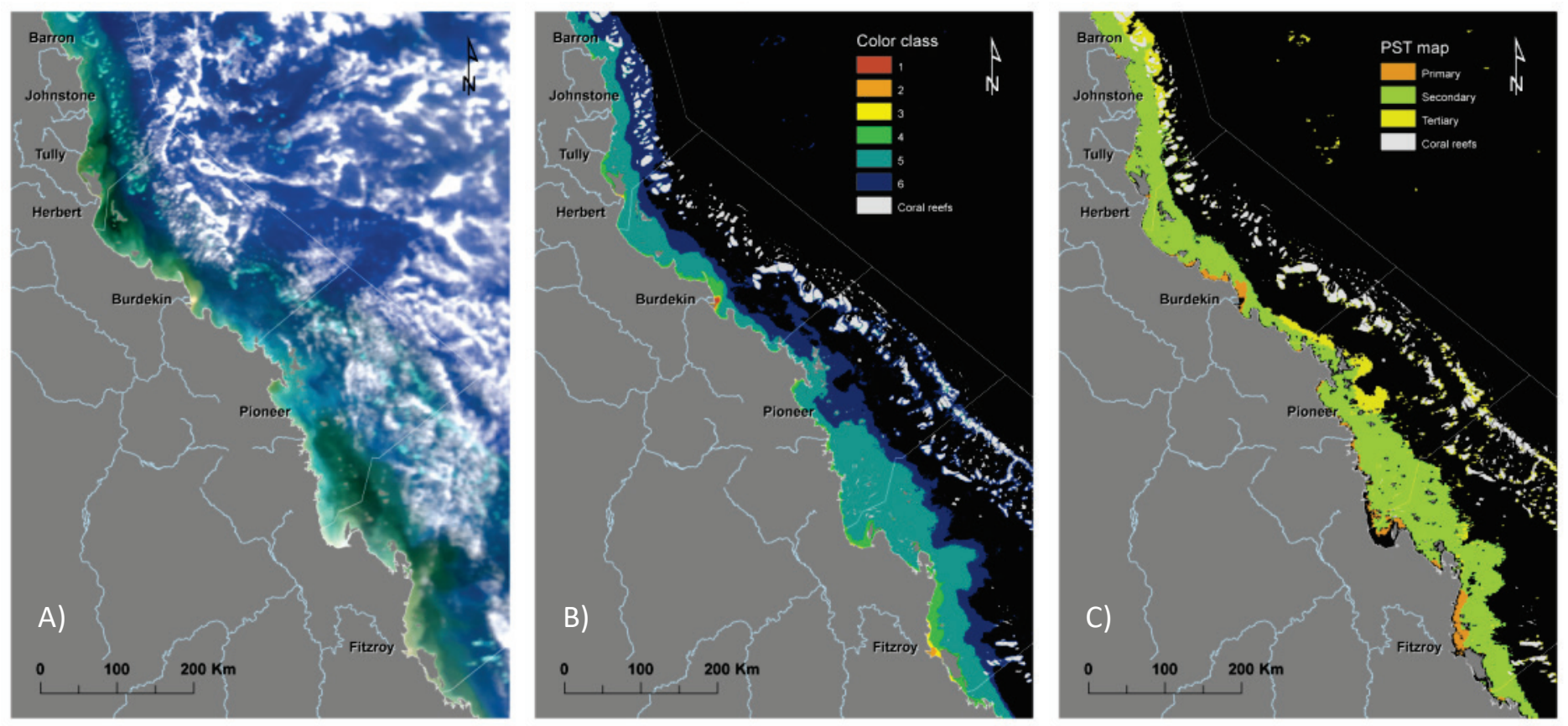

Figure 4. MODIS-Aqua image and mapped plumes for major rivers of the GBR, January 25, 2011. A) MODIS true-color image; B) 6-class plume map indicative of gradients in L2 parameters used in this study to assess exposure, where red (class 1) represents the highest exposure and blue (class 6) the lowest; and C) plume map depicting the three water types: primary (P), secondary (S) and tertiary ( $T$ ) using the classification algorithm of Devlin et al. (2012b) based on ocean color (L2) parameters. In B and C, black areas indicate non-plume areas or portions of the image that were automatically masked out in SeaDAS (only for the PST map) in the processing of ocean color parameters due to the presence of clouds or very turbid areas (resembling land). 


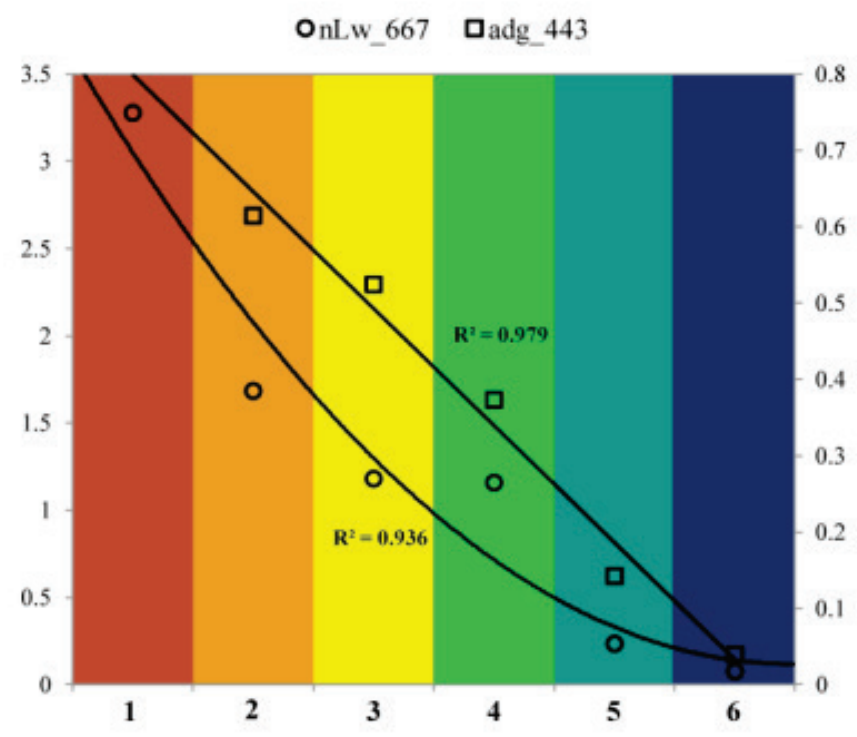

Figure 5. Variation in ocean color (L2) parameters across the six color classes identified using unsupervised classification. Graphs summarize data from 25 selected images that cover different regions of the GBR with plumes of different size and with an observable gradient in surface color classes, from very turbid brown (class 1 ) to mostly green water masses (class 5) and plume edge (class 6). Points are mean values for the two selected L2 parameters based on their recorded values within each color class for the 25 images. The left $Y$-axis corresponds to the normalized water-leaving radiance at $667 \mathrm{~nm}$ (nlw_667), an L2 parameter used as a proxy for TSS. The right $Y$-axis indicates the variation in the CDOM and detritus absorption coefficient at $443 \mathrm{~nm}$ (adg_443), a parameter used as a proxy for variation in dissolved pollutants (e.g., DIN). Mean value for class 1 (very high TSS) of adg_443 (proxy for DIN) was excluded because the performance of standard algorithms for CDOM+D in highly turbid areas is low (Qin et al., 2007). The observed gradients observed in this graph were the basis for the functions used to calculate the cost surfaces for TSS and DIN (Figure 3).

\subsubsection{Frequency of occurrence of plume and color classes}

Overlaying weekly composites of plumes showed the total area influenced by plumes and areas where plumes occur more or less frequently (calculated for each year independently), which approximates annual exposure to plumes (Figure 6A). The mean color class value across all weeks (indicative of a gradient in L2 parameters; see Figure 5) corresponds to the grid (Figure 6B) used to represent dispersal of pollutants based on the functions described in Figure 3. Inter-annual variation in both frequency and mean color classes (Supplementary Material) was reflected in the observed variation in exposure described in section 3.1.5.

\subsubsection{Proportional contribution of rivers}

The delivery of DIN and TSS varied considerably between rivers, and relative delivery of rivers varied strongly between wet seasons (Figure 7). Overall, the two major rivers of the Dry Tropics (Burdekin and Fitzroy) contributed considerably to the region-wide DIN (49\% to $72 \%$ ) and TSS (80\% to 94\%) loads across all five wet seasons. Conversely, the summed proportional contribution of the Wet Tropics' rivers (Barron, Johnstone, Tully and Herbert) was prominent for DIN (25\% to $46 \%$ ) but not for TSS (5\% to 19\%). Two rivers, the Herbert and the Tully, dominated the contribution of TSS and DIN loads in this NRM region. There was marked inter-annual variation in the proportional contributions of the two large Dry Tropics rivers (i.e., the average of the absolute deviations from the contribution of the Burdekin and Fitzroy rivers are $11 \%$ and $15 \%$ for DIN and $23 \%$ and $21 \%$ for TSS, respectively, while the average for all other rivers is only $2 \%$ and $1 \%$ ). This indicates that areas under the influence of the two largest rivers are subject to more marked inter-annual delivery of pollutants, manifested in the patterns of exposure described below (sections 3.1.4 and 3.1.5). 

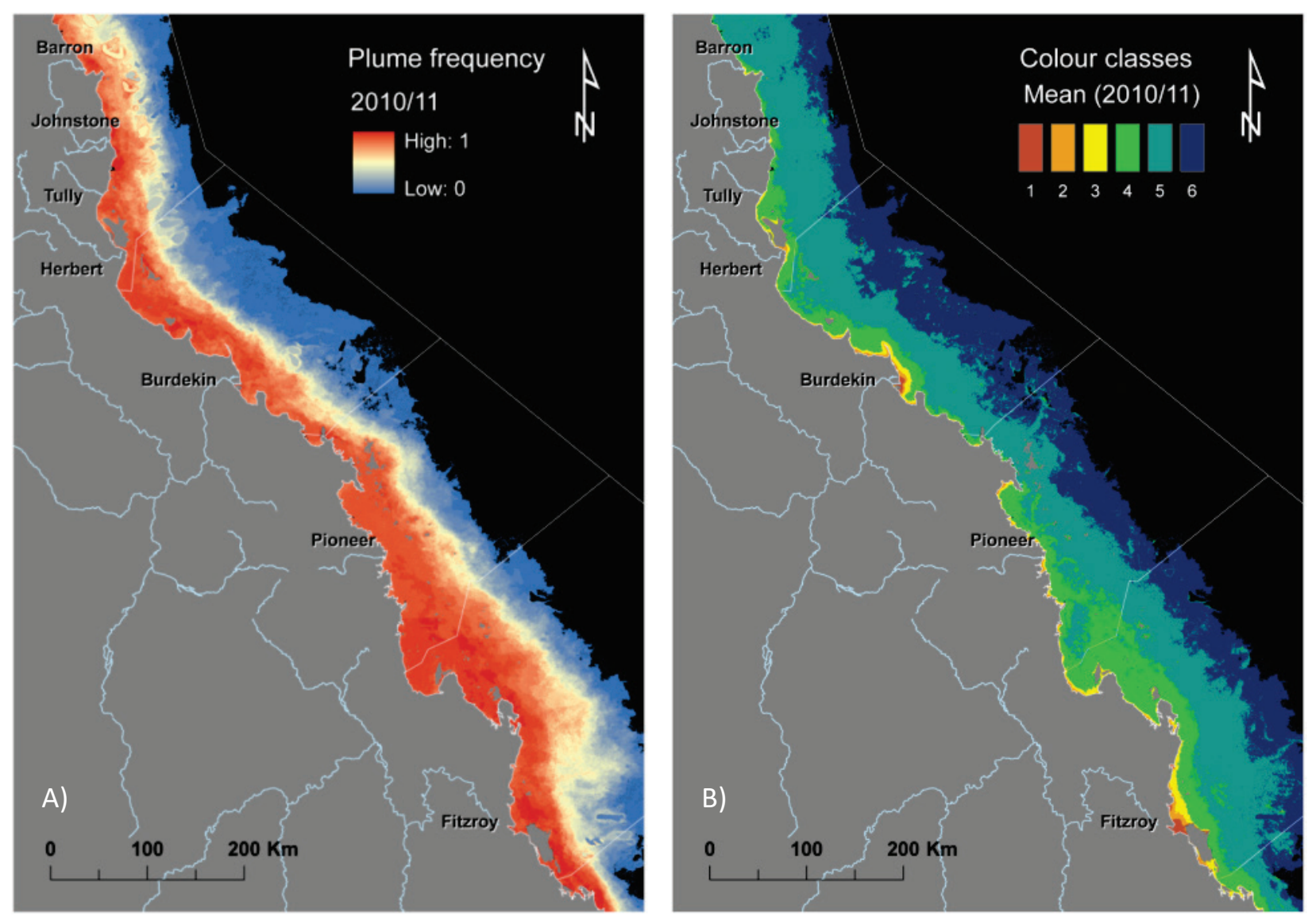

Figure 6. Example of summary maps of plume occurrence used as inputs in the plume exposure model. In this case, the images correspond to the 2011 wet season. A) annual frequency of plume occurrence (the dark red color identifies areas influenced by plumes for most weeks during the wet season, while blue areas are indicative of areas rarely exposed to plumes); and B) mean color class value across all weeks (see Figure 5), indicative of the average pattern of pollutant dispersal during the wet season for that year. The color-coding is the same used in Figure 5. Black areas indicate nonplume areas.

\section{A) DIN}

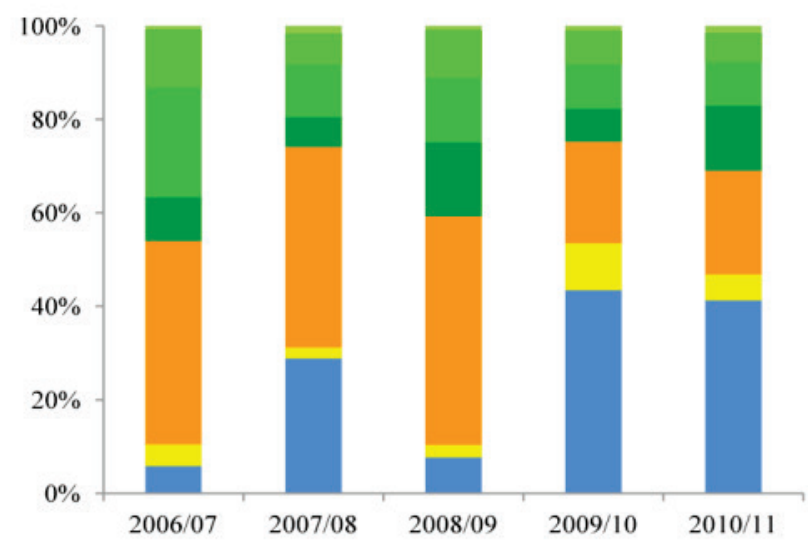

B) TSS

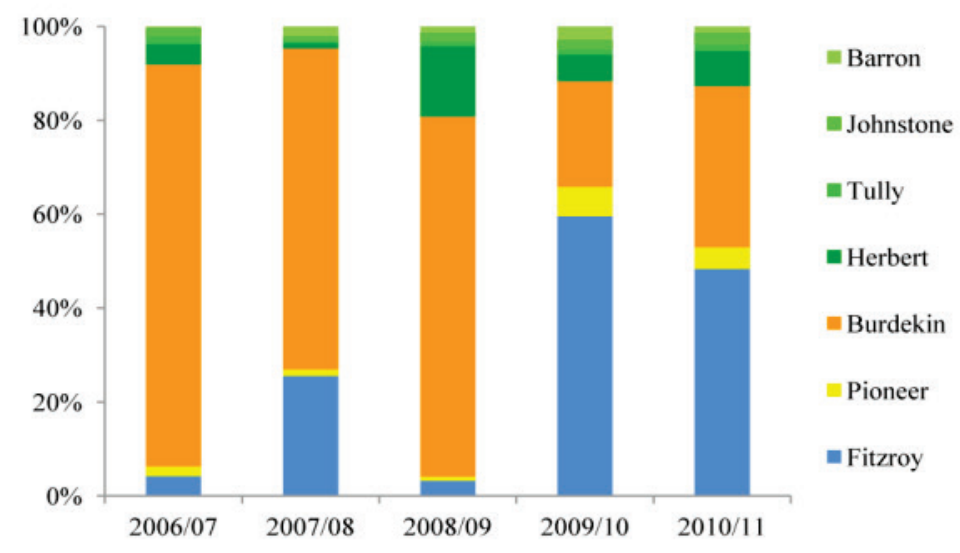

Figure 7. Proportional contribution of major rivers to region-wide pollutant loads in each of the five wet seasons covered by this study. A) Dissolved inorganic nitrogen (DIN) and B) Total suspended sediment (TSS). Rivers identified by green colors in the bars correspond to rivers in the Wet Tropics NRM (Figure 1). 


\subsubsection{Spatially distributed pollutant loads}

The TSS and DIN cost surfaces (Figure 8A,B) - used to represent differences in TSS and DIN dispersal and to create the grids of spatially distributed loads - showed the expected spatial pattern of pollutant movement (Devlin and Schaffelke, 2009), and reflected the exposure patterns to these pollutants (Figure 8). Overall, we observed that the area estimated to be under major influence of DIN (identified as red to light green areas, Figure $8 \mathrm{C}$ ) is notably larger than that under major influence of TSS (Figure 8D), which reflects the expected rapid deposition of sediment in areas near river mouths (Bainbridge et al., 2012).

\subsubsection{Annual exposure of ecosystems to DIN and TSS}

Coastal-marine ecosystems (coral reefs and seagrass beds) exhibited a range of exposures to DIN and TSS, reflecting the differences in the dispersal of pollutants and the locations of the ecosystems (Figure 9). The area under moderate to high exposure to DIN was larger than that for TSS across all studied wet seasons. Data for 2011, a wet season in which record discharges occurred, illustrated the degree of exposure that can be expected under extreme weather conditions (Devlin et al., 2012a), also manifested in the very extensive plumes within GBR coastal and offshore waters during this wet season (Figure 10).

Also worth noting are the differences in exposure of different ecosystems to DIN and TSS in relation to the natural distribution of these ecosystems, as well as to the differences in the movements of pollutants. Overall, seagrass beds were commonly under higher exposure categories for both TSS and DIN, and most coral reefs were under low exposure categories, particularly for TSS (Figure 9). 

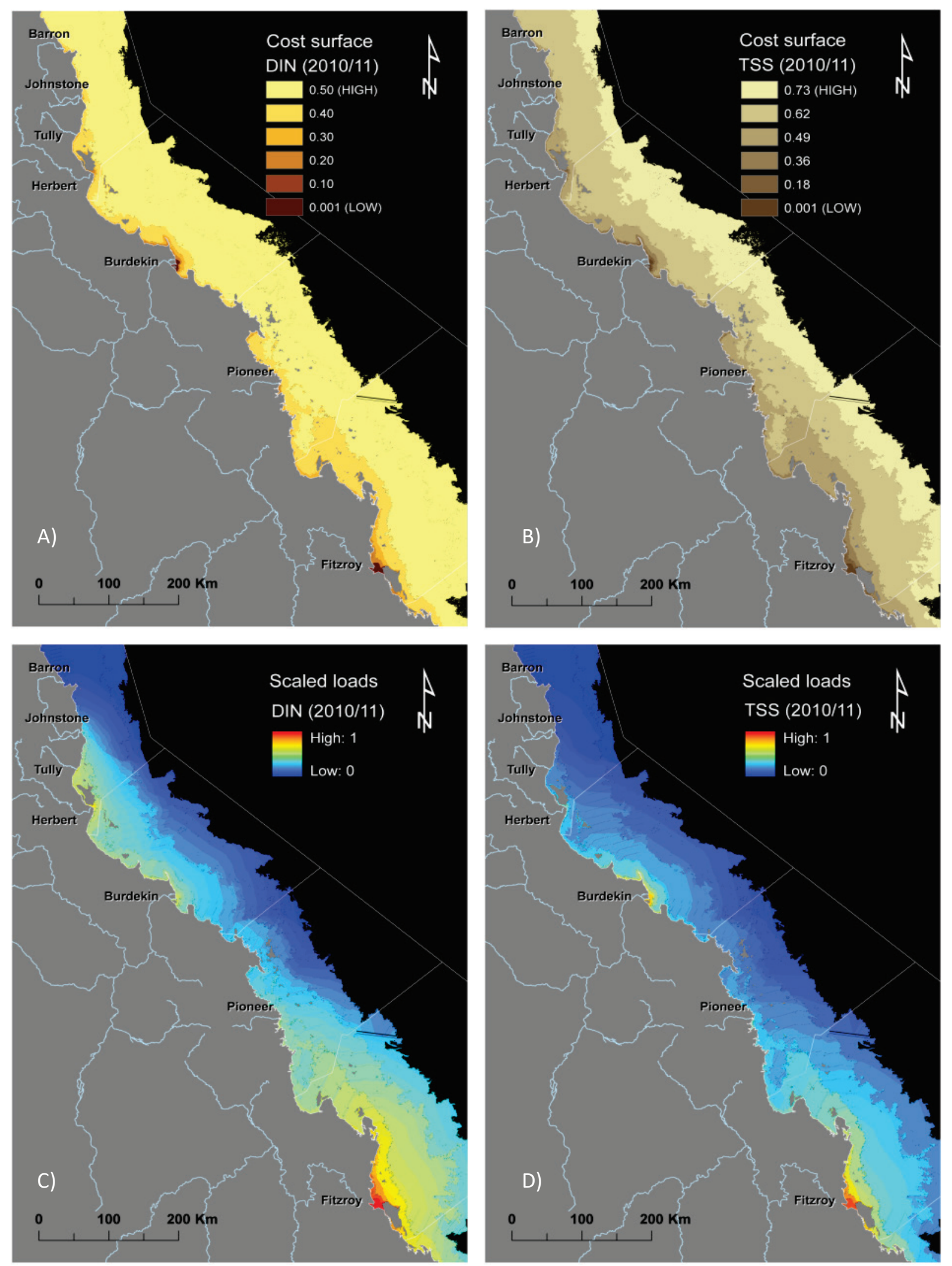

Figure 8. Cost surfaces and scaled loads for dissolved inorganic nitrogen (DIN) and total suspended sediment (TSS). A) Cost surface used to calculate the scaled (i.e., spatially distributed) loads of DIN presented in C for the 2011 wet season. The proportional increase in cost from the river mouths to offshore areas approximates the patterns of dispersal of DIN. B) Cost surface used to calculate the scaled (i.e., spatially distributed) loads of TSS presented in D for the 2011 wet season. The patterns of the cost surfaces are reflected in the grids representing the scaled loads for DIN (C) and TSS (D), which can be interpreted as the probability of pollutants reaching a given area during the wet season of that year. 

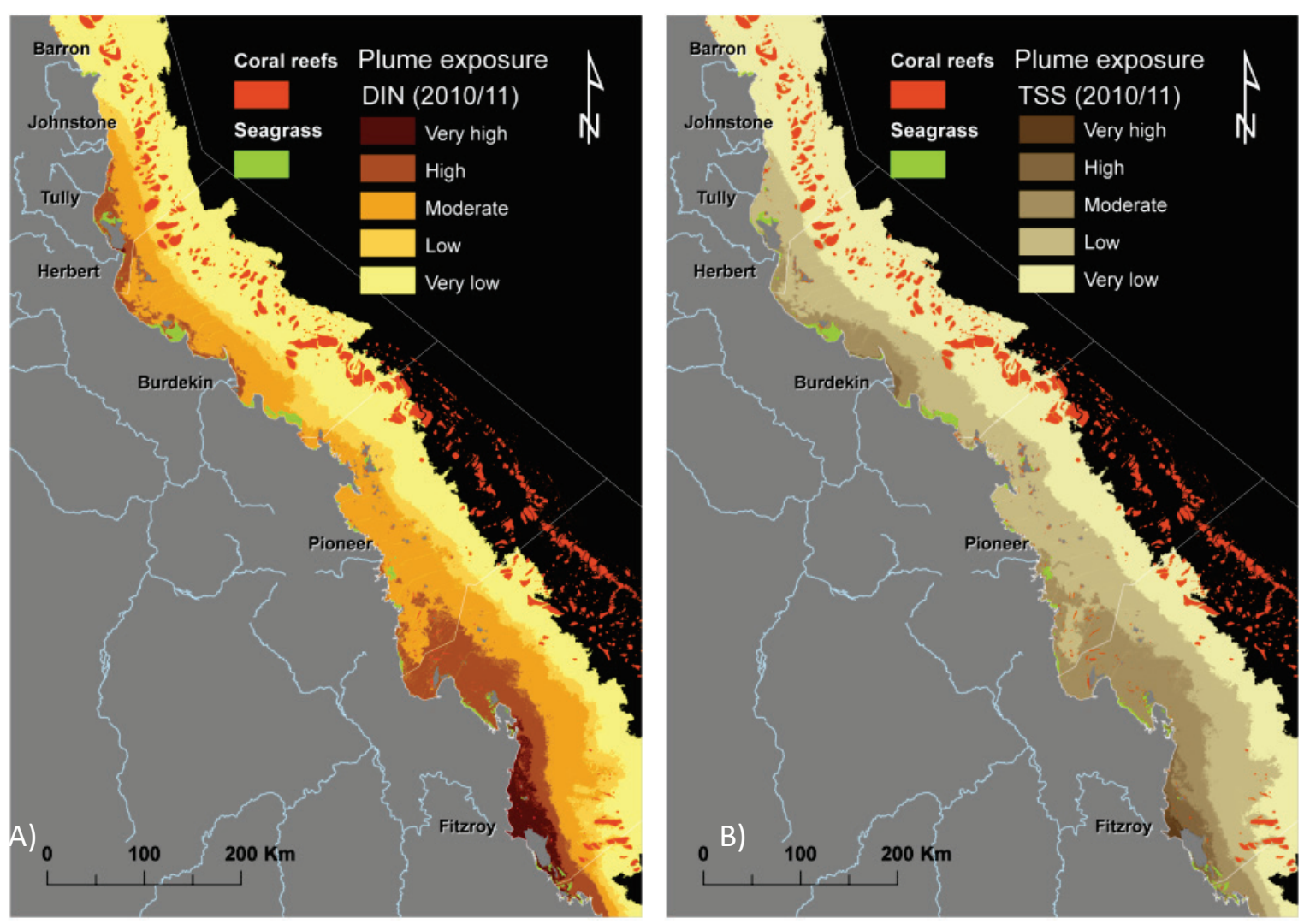

Figure 9. Maps of annual exposure of coral reefs and seagrass beds to DIN (A) and TSS (B) for the 2011 wet season. The progression in intensity of color indicates the degree of exposure to these pollutants. The distribution of seagrass beds in nearshore areas led to their higher exposure to both pollutants. Because of their proximity to the coast, coral reefs located within the Wet Tropics NRM are relatively more exposed to both pollutants comparison to coral reefs of the Mackay-Whitsunday and Fitzroy NRMs.

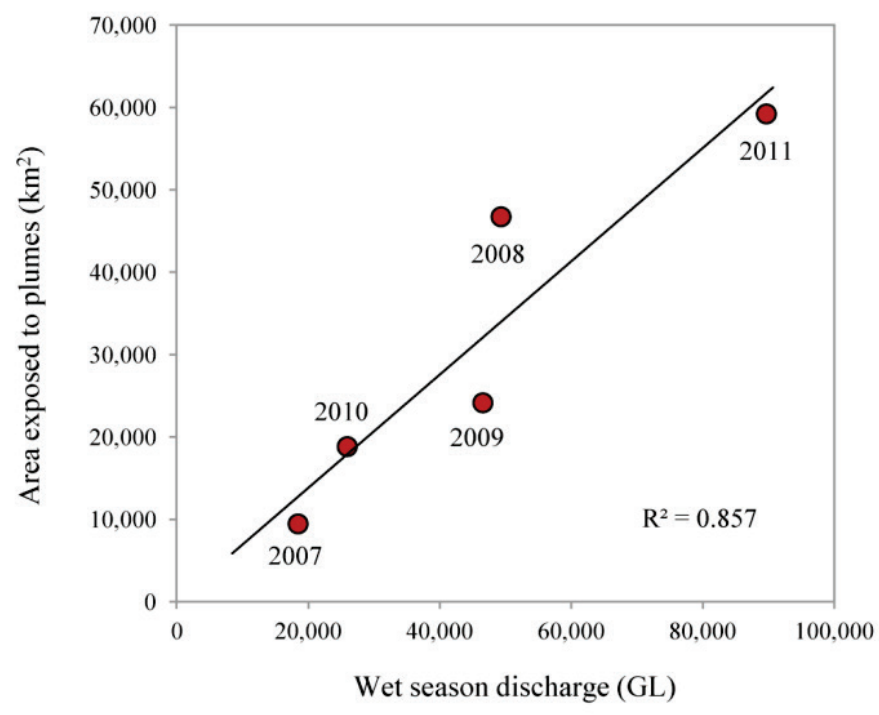

Figure 10. Relationship between the modeled maximum plume extents and recorded discharges. Each point represents the summed total discharge and the estimated area exposed to plumes for the wet season of that year. The graph shows a clear relation between discharge and the area of influence, and identifies wet years (e.g., 2008 and 2011), which were also characterized by large loads of TSS and DIN, and hence large areas under higher exposure categories. 


\subsection{Spatial-temporal variability in plume exposure}

We found strong inter-annual variation in the areas exposed to the two modeled pollutants (Figure 11). Differences in exposure were related to the sources of pollutants, and thus were strongly influenced by the proportional contributions of the different rivers to annual region-wide loads. The area of coral reefs and seagrass beds potentially affected by TSS and DIN exposure also varied considerably between years, with maximum numbers of coral reefs affected in 2011 (Figure 12). TSS exposure was high in both $2008 / 9$ and $2010 / 11$. Overall, while the exposed areas were sometimes large, the areas influenced by high to very high exposure categories was a small component for both DIN and TSS, with the exception of DIN in 2011.
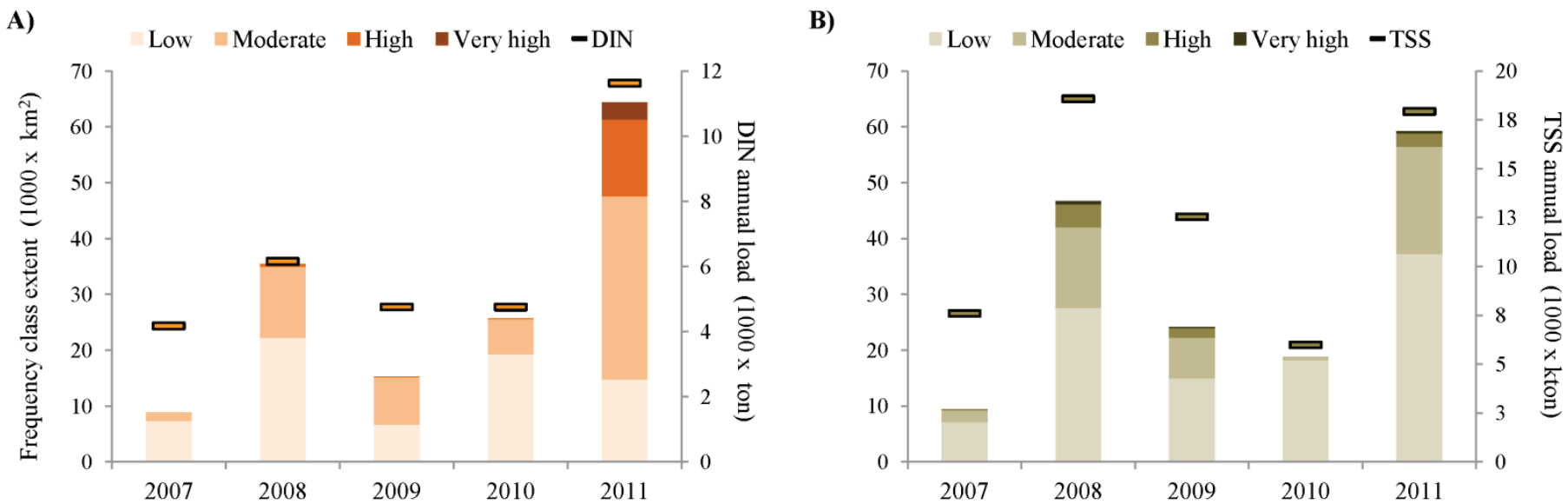

Figure 11. Inter-annual variation in total area under different DIN/TSS exposure categories. A) Variation in exposure to DIN. This graph shows the large area under high exposure categories during 2011 (greatly influenced by the Fitzroy River: Figure 7A). B) Variation in exposure to TSS; in contrast to DIN, the largest area under high TSS exposure categories occurred during 2008 (in this case, largely driven by the Burdekin River: Figure 7B). In both graphs, the horizontal bars correspond to the estimated loads of DIN (A) and TSS (B) for each wet season. 

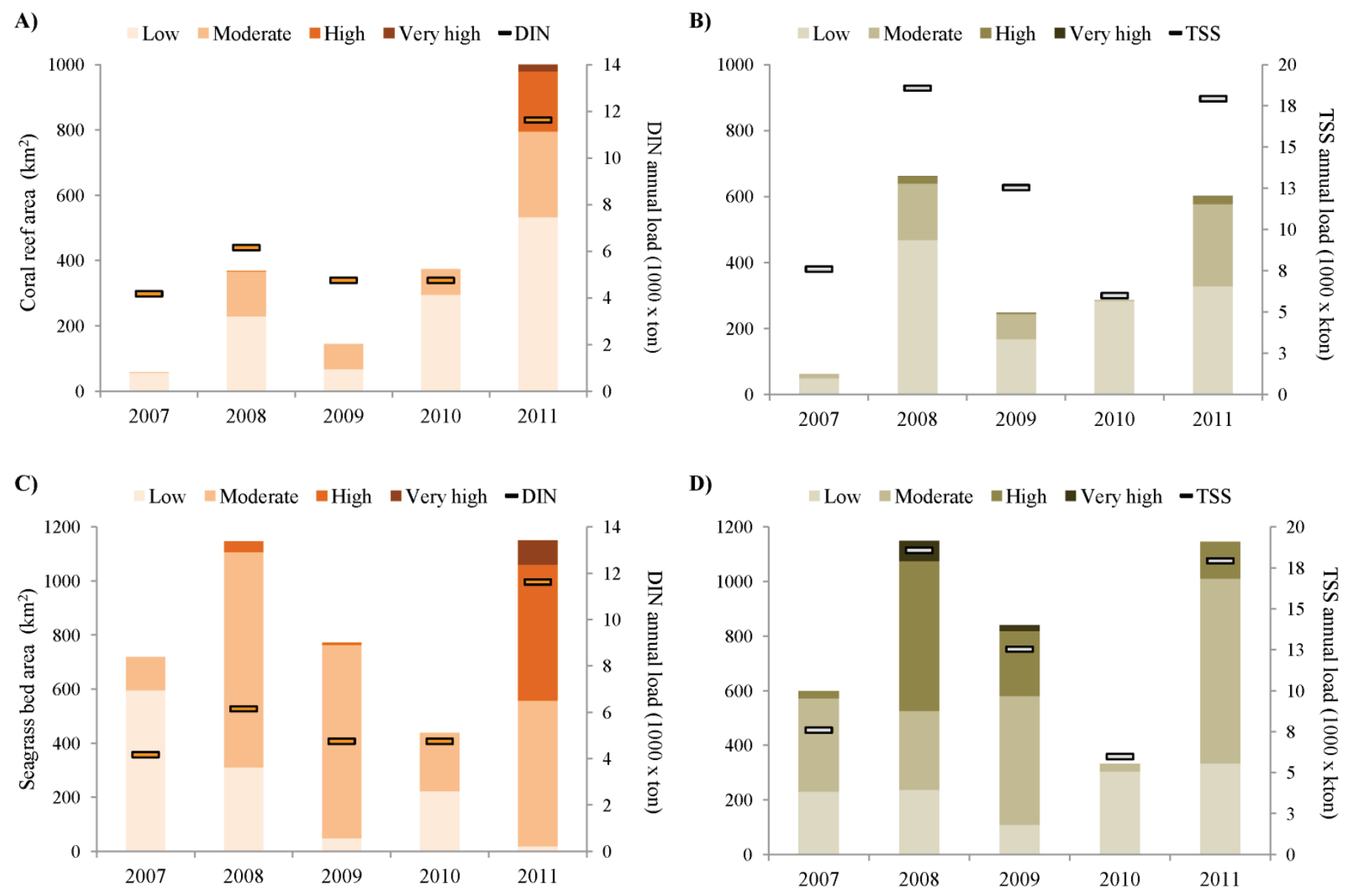

Figure 12. Inter-annual variation in exposure of coral reefs and seagrass beds to DIN (A and C, respectively) and TSS (B and $D$, respectively). The observed differences in exposure of ecosystems to TSS and DIN can be explained by their proximity to the coast, their location in relation to rivers contributing to pollutant loads, and the estimated dispersal of both pollutants. In both graphs, the horizontal bars connected by dashed lines correspond to the estimated loads of DIN (A and C) and TSS (B and D) for each wet season.

\section{Discussion}

Understanding the dynamics and potential impacts of land-based threats on coastal-marine ecosystems is a critical step towards minimizing these impacts. Our study made improvements to river-plume exposure models in two ways: first, by developing a relatively simple method to map the extent and qualitatively assess dispersal of land-based pollutants; and second, by assessing spatial-temporal variability in the exposure of marine ecosystems to plumes. Our work thus contributes to our understanding on the spatial-temporal dynamics of plumes in the Great Barrier Reef region and offers a method to improve plume exposure models developed for the GBR and elsewhere. The method is transferable to other regions, and can be scaled up or down to model regions of widely varying extents.

Manual mapping of plumes has been used to model exposure, but is very time consuming, requires significant experience, and is not very precise. In addition, methods based on L2 ocean-color products are affected by atmospheric and water conditions. Classification of true-color images allows more information to be retrieved from imagery (even under moderate cloud cover and sun glint conditions, or in very turbid areas). Our approach also automates the mapping of images, thus reducing processing time and human error associated with visual interpretation of plumes. Our exposure model further improves current methods by incorporating a simple way to integrate the dispersal of pollutants into river plume maps. In contrast, previous approaches applied a uniform value (representing the proportional contribution of an NRM to the region-wide loads) across for the whole NRM surface (Devlin et al., 2012b). An additional advantage of our approach is that exposure to pollutants throughout the GBR can be linked to specific rivers. This information is critical 
because, used in combination with maps of pollutant sources, it can guide targeting of catchment management to benefit particular habitats and parts of the GBR (Brodie et al., 2009). Our method also allows the identification of areas likely influenced by multiple rivers, hence incorporating a measure of cumulative impact. Our relatively simple approach to mapping plumes and modeling exposure also facilitates the processing of large numbers of images, thus permitting the assessment of spatial-temporal variability across large regions and long periods.

In the Great Barrier Reef, more accurate and consistent mapping of river plumes and derived exposure models could be important for monitoring land-based impacts and adjusting catchment management to minimize or mitigate those impacts. Land-based pollutants are recognized as major stressors on coastal-marine ecosystems in the region (Brodie et al., 2012b), in particular for vulnerable habitats such as coral reefs (Fabricius, 2011) and seagrass beds (McKenzie and Unsworth, 2011). For instance, large-scale mortality events associated with waters of low salinity and high temperature caused by flood conditions have been documented for the region's coral reefs (Berkelmans, 2009) and seagrass beds (McKenzie and Unsworth, 2011; Waycott et al., 2005). Flood plumes can result in low light levels in seagrass beds and coral reefs. Reduced exposure to light can cause lethal and sub-lethal conditions for photosynthetic organisms such as seagrass and coral symbionts (Collier et al., 2012; Cooper et al., 2008). Other long-term ecological impacts can be seen in the proliferation of coral-reef destroying crown-of-thorn starfish in areas regularly influenced by anthropogenic nutrient loads (Brodie et al., 2005; Fabricius et al., 2010). Recent seagrass mortality events associated with the 2011 wet season have also been related to increased mortality of dugongs and sea turtles in the GBR (McKenzie et al., 2012; McKenzie et al., 2010), highlighting the importance of studying variation in exposure to pollutants through time and its relation to observed ecological responses.

While our plume model was developed using the Great Barrier Reef as a case study, the approach is applicable to other regions, scales and pollutants. Although we expect that similar relationships between ocean parameters and plume characteristics can be found in other regions, calibration of functions used to model dispersal of pollutants is advisable. Changes in concentration, composition, size distribution, shape, and refractive index of suspended, organic and inorganic marine particles affect the backscattering and absorption properties of water (Binding et al., 2005; Bricaud et al., 1995), and hence its intrinsic color. Information regarding loads was available for our study area through a long-term monitoring program (Carroll et al., 2012), but this information may not be available for many regions. Under these data-limited circumstances the use of catchment models (Source Catchments, eWater_CRC, 2010; e.g., SedNet, Wilkinson et al., 2004) to estimate pollutant loads is a good alternative (Alvarez-Romero et al., In review). The approach for modeling exposure to DIN can be used for other dissolved pollutants (e.g., dissolved inorganic phosphorus, pesticides), thus extending the potential application of our model. However, the complex interactions between different pollutants (e.g., floculation: Bainbridge et al., 2012) and non-conservative mixing of some of these and other pollutants (i.e., their concentration gradient does not match that of salinity), such as particulate nutrients (Brodie et al., 2012a) warrants further investigation to adjust these models as necessary.

Some limitations are inherent in our plume modeling approach, some of which also apply to other ocean-color remotesensing applications (e.g., classification algorithms based on L2 products). One aspect that requires careful consideration when applying the proposed model is the presence of other surface water masses that resemble plume waters (see Figure 4B/C, where color classes 5 and 6, and secondary/tertiary plumes are mapped in offshore reefs not associated with plumes). One example is the periodic upwelling of nutrient-rich water that feeds colorful phytoplankton blooms, which can be confused with chlorophyll-rich plume waters (Beman et al., 2005). Another example is the resuspension of terrigeneous fine sediments by currents, wind generated waves, and tides in the period after floods (Fabricius, 2011; Orpin et al., 1999). The latter situation can be observed in Shoalwater Bay, north of the Fitzroy River, where very turbid areas occur in the absence of plumes, mostly associated with strong tidal currents (Kleypas, 1996). Our model partially deals with these problems by focusing analysis on the wet season, masking out coral reefs and applying a cost-distance function. However, further refinement could improve the model, for example through time-series analysis to help discern between high productivity areas associated with seasonal oceanographic and atmospheric conditions, and analysis of imagery during the dry season to identify areas of high turbidity associated with wind driven and tidal resuspension. Furthermore, the model might not accurately map plumes in shallow and narrows where bottom influence and radiance reflected back from adjacent land can contaminate signals recorded by the satellite (Doxaran et al., 2009; Ohde and Siegel, 2001). 
Our model focuses on surface exposure and is therefore limited in predicting the vertical extent of plumes or the mixing that is occurring in the water column. More work is needed to further understand how the pollutants carried in the flood plume become incorporated in the water near the seabed. Hydrodynamic models could be used to predict the dispersal and mixing of plumes and pollutants, but such models are not available in most regions, or if available, are not at resolutions conducive to plume modeling. Another potential improvement is the modeling of exposure at finer temporal resolutions. If weekly load data are available (e.g., linked to a catchment model such as Source Catchments: Carroll et al., 2012), our plume model can be adjusted to produce exposure models that represent variability at weekly time-steps.

Further investigations that can improve our model include validation of our TSS/DIN proxies against in situ measurements, exploration of the effects of using an ad hoc RGB stretch when producing true-color images, and adjustment of spectral signatures used in the supervised classification to account for potential seasonal and/or inter-annual variations.

\section{Conclusions}

Maps resulting from plume exposure models can be useful for a variety of applications, especially to monitor coastalmarine water quality and prioritize catchment management for marine conservation planning. The model described here, in combination with methods based on ocean-color parameters (Devlin et al., 2012b; Schroeder et al., 2012), has obvious applications for monitoring, because it could be a tool to periodically assess exposure of marine ecosystems to land-based pollutants. The outputs of our model are useful for conservation because understanding the dynamics and potential impacts of land-based threats is necessary to identify spatial alternatives that can minimize vulnerability and maximize conservation outcomes. These alternatives include avoiding imminent threats, where possible (e.g., by locating marine conservation areas away from areas strongly affected by land-based pollutants: Tallis et al., 2008), targeting catchment areas to minimize the supply of pollutants and improve end-of-river water quality (Brodie et al., 2009; Devlin et al., $2012 b$ ), and/or combining these strategies while assessing the trade-offs between them in different areas (Klein et al., 2010). To explore these options, planners require models of land-based threats that, ideally, integrate information on: i) the spatial distribution of pollutant sources; ii) the loads of land-based pollutants discharged into the sea; iii) the dispersal of these pollutants in the sea; and iv) the potential ecological impacts of degraded water quality. Our model integrates the second and third elements, and can be linked to the first one through catchment modeling. Exploration of the correspondence of our exposure model to observed ecological changes (e.g., occurrence of COTS outbreaks, Fabricius et al., 2010; and declines in coral cover, Hughes et al., 2011; Sweatman et al., 2011), is yet to be investigated. Until now, incorporation of land-based threats in conservation planning applications has been limited (Alvarez-Romero et al., 2011), so studies aiming to integrate these all four types of information described above should be considered a priority.

\section{Acknowledgements}

We thank Gordon Bailey for providing IT support and the High Performance Computing Unit at James Cook University for computational facilities. JGAR gratefully acknowledges support from Mexico's Consejo Nacional de Ciencia y Tecnología (CONACYT) and Secretaría de Educación Pública (SEP), as well as from the Australian Research Council Centre of Excellence for Coral Reef Studies, the Centre for Tropical Water and Aquatic Ecosystem Research (TropWATER) and Comisión Nacional para el Conocimiento y Uso de la Biodiversidad (CONABIO). RLP and NCB acknowledge the support of the Australian Research Council.

\section{References}

Alvarez-Romero, J.G., Pressey, R.L., Ban, N.C., Torre, J., Aburto-Oropeza, O., In review. Marine conservation planning in practice: lessons learned from the Gulf of California. Aquatic Conservation: Marine and Freshwater Ecosystems.

Alvarez-Romero, J.G., Pressey, R.L., Ban, N.C., Vance-Borland, K., Willer, C., Klein, C.J., Gaines, S.D., 2011. Integrated land-sea conservation planning: the missing links. Annual Review of Ecology, Evolution, and Systematics 42, 381-409.

Bainbridge, Z., Wolanski, E., Alvarez-Romero, J.G., Lewis, S., Brodie, J., 2012. Fine sediment and nutrient dynamics related to particle size and floc formation in a Burdekin River flood plume, Australia. Marine Pollution Bulletin 65, $236-248$.

Baith, K., Lindsay, R., Fu, G., McClain, C.R., 2001. SeaDAS, a data analysis system for ocean color satellite sensors. Eos Trans. AGU 82, 202.

Ball, G.H., Hall, D.J., 1965. A Novel Method of Data Analysis and Pattern Classification. Stanford Research Institute, Menlo Park, California. 
Beman, J.M., Arrigo, K.R., Matson, P.A., 2005. Agricultural runoff fuels large phytoplankton blooms in vulnerable areas of the ocean. Nature 434, 211-214.

Berkelmans, R., 2009. Bleaching and mortality thresholds: how much is too much?, in: van Oppen, M.J.H., Lough, J. (Eds.), Coral bleaching: patterns, processes, causes and consequences. Springer-Verlag, Berlin, Germany, pp. 103-119.

Binding, C.E., Bowers, D.G., Mitchelson-Jacob, E.G., 2005. Estimating suspended sediment concentrations from ocean colour measurements in moderately turbid waters; The impact of variable particle scattering properties. Remote Sensing of Environment 94, 373-383.

Brando, V., Schroeder, T., Dekker, A., Park, Y., 2010. Reef Rescue Marine Monitoring Program: using remote sensing for GBR wide water quality, final report for 2009/10 activities. CSIRO, Canberra, ACT.

Bricaud, A., Babin, M., Morel, A., Claustre, H., 1995. Variability in the chlorophyll-specific absorption coefficients of natural phytoplankton: analysis and parameterization. Journal of Geophysical Research 100, 13321-13332.

Brodie, J., Devlin, M., Haynes, D., Waterhouse, J., 2011. Assessment of the eutrophication status of the Great Barrier Reef lagoon (Australia). Biogeochemistry 106, 281-302.

Brodie, J., Fabricius, K., De'ath, G., Okaji, K., 2005. Are increased nutrient inputs responsible for more outbreaks of crown-of-thorns starfish? An appraisal of the evidence. Marine Pollution Bulletin 51, 266-278.

Brodie, J., Lewis, S., Bainbridge, Z., Mitchell, A., Waterhouse, J., Kroon, F., 2009. Target setting for pollutant discharge management of rivers in the Great Barrier Reef catchment area. Marine and Freshwater Research 60, 1141-1149.

Brodie, J., Schroeder, T., Rohde, K., Faithful, J., Masters, B., Dekker, A., Brando, V., Maughan, M., 2010. Dispersal of suspended sediments and nutrients in the Great Barrier Reef lagoon during river-discharge events: conclusions from satellite remote sensing and concurrent flood-plume sampling. Marine and Freshwater Research 61, 651-664.

Brodie, J., Wolanski, E., Lewis, S., Bainbridge, Z., 2012a. An assessment of residence times of land-sourced contaminants in the Great Barrier Reef lagoon and the implications for management and reef recovery. Marine Pollution Bulletin In Press.

Brodie, J.E., Kroon, F.J., Schaffelke, B., Wolanski, E.C., Lewis, S.E., Devlin, M.J., Bohnet, I.C., Bainbridge, Z.T., Waterhouse, J., Davis, A.M., 2012b. Terrestrial pollutant runoff to the Great Barrier Reef: An update of issues, priorities and management responses. Marine Pollution Bulletin In Press.

Butchart, S.H.M., Walpole, M., Collen, B., van Strien, A., Scharlemann, J.P.W., Almond, R.E.A., Baillie, J.E.M., Bomhard, B., Brown, C., Bruno, J., Carpenter, K.E., Carr, G.M., Chanson, J., Chenery, A.M., Csirke, J., Davidson, N.C., Dentener, F., Foster, M., Galli, A., Galloway, J.N., Genovesi, P., Gregory, R.D., Hockings, M., Kapos, V., Lamarque, J.-F., Leverington, F., Loh, J., McGeoch, M.A., McRae, L., Minasyan, A., Morcillo, M.H., Oldfield, T.E.E., Pauly, D., Quader, S., Revenga, C., Sauer, J.R., Skolnik, B., Spear, D., Stanwell-Smith, D., Stuart, S.N., Symes, A., Tierney, M., Tyrrell, T.D., Vie, J.-C., Watson, R., 2010. Global Biodiversity: Indicators of Recent Declines. Science, science.1187512.

Cabaco, S., Santos, R., Duarte, C.M., 2008. The impact of sediment burial and erosion on seagrasses: A review. Estuar. Coast. Shelf Sci. 79, 354-366.

Carroll, C., Waters, D., Vardy, S., Silburn, D.M., Attard, S., Thorburn, P.J., Davis, A.M., Halpin, N., Schmidt, M., Wilson, B., Clark, A., 2012. A Paddock to reef monitoring and modelling framework for the Great Barrier Reef: Paddock and catchment component. Marine Pollution Bulletin In Press.

CBD, 2006. Global Biodiversity Outlook 2. Secretariat of the Convention on Biological Diversity, Montreal, Canada.

Cherubin, L.M., Kuchinke, C.P., Paris, C.B., 2008. Ocean circulation and terrestrial runoff dynamics in the Mesoamerican region from spectral optimization of SeaWiFS data and a high resolution simulation. Coral Reefs 27, 503-519.

Cloern, J.E., 1996. Phytoplankton bloom dynamics in coastal ecosystems: A review with some general lessons from sustained investigation of San Francisco Bay, California. Rev. Geophys. 34, 127-168.

Collier, C.J., Waycott, M., McKenzie, L., 2012. Light thresholds derived from seagrass loss in the coastal zone of the northern Great Barrier Reef, Australia. Ecological Indicators 23, 211-219.

Cooper, T.F., Ridd, P.V., Ulstrup, K.E., Humphrey, C., Silvcoff, M., Fabricius, K., 2008. Temporal dynamics in coral bioindicators for water quality on coastal coral reefs of the Great Barrier Reef. Marine and Freshwater Research 59, 703-716.

Croke, J.C., Hairsine, P.B., 2006. Sediment delivery in managed forests: a review. Environ. Rev. 14, 59-87.

Day, J., 2011. Great Barrier Reef Marine Park: governance analysis, in: Jones, P.J.S., Qiu, W., De Santo, E.M. (Eds.), Governing Marine Protected Areas: getting the balance right: technical report to Marine \& Coastal Ecosystems Branch, UNEP. United Nations Environmental Programme (UNEP), Cambridge, UK, pp. 1-18.

Devlin, M., Brodie, J., Wenger, A., Teixeira da Silva, E., Alvarez-Romero, J.G., Waterhouse, J., McKenzie, L., 2012a. Chronic and acute influences on the Great Barrier Reef: putting extreme weather conditions in context, Proceedings of the 12 th International Coral Reef Symposium, Cairns, Australia.

Devlin, M., McKinna, L.I., Alvarez-Romero, J.G., Petus, C., Abbot, B., Harkness, P., Brodie, J., 2012b. Mapping the pollutants in surface riverine flood plume waters in the Great Barrier Reef, Australia. Marine Pollution Bulletin 65, 224-235.

Devlin, M., Schaffelke, B., 2009. Spatial extent of riverine flood plumes and exposure of marine ecosystems in the Tully coastal region, Great Barrier Reef. Marine and Freshwater Research 60, 1109-1122. 
Devlin, M., Schroeder, T., McKinna, L.I., Brodie, J., Brando, V., Dekker, A., 2011. Monitoring and mapping of flood plumes in the Great Barrier Reef based on in-situ and remote sensing observations, in: Chang, N.-B. (Ed.), Environmental Remote Sensing and Systems Analysis. CRC Press, Online.

Devlin, M., Waterhouse, J., Taylor, J., Brodie, J., 2001. Flood plumes in the Great Barrier Reef: spatial and temporal patterns in composition and distribution, GBRMPA Research Publication. Great Barrier Reef Marine Park Authority (GBRMPA), Townsville, QLD.

Devlin, M.J., Brodie, J., 2005. Terrestrial discharge into the Great Barrier Reef Lagoon: nutrient behavior in coastal waters. Marine Pollution Bulletin 51, 9-22.

Diaz, R.J., Rosenberg, R., 2008. Spreading dead zones and consequences for marine ecosystems. Science 321, 926-929.

Doxaran, D., Froidefond, J.-M., Castaing, P., Babin, M., 2009. Dynamics of the turbidity maximum zone in a macrotidal estuary (the Gironde, France): Observations from field and MODIS satellite data. Estuarine, Coastal and Shelf Science 81, 321-332.

Duke, N.C., Bell, A.M., Pederson, D.K., Roelfsema, C.M., Nash, S.B., 2005. Herbicides implicated as the cause of severe mangrove dieback in the Mackay region, NE Australia: consequences for marine plant habitats of the GBR World Heritage Area. Marine Pollution Bulletin 51, 308-324.

ERDAS, 2010. Image Analysis for ArcGIS. ERDAS, Inc., Norcross, GA.

ESRI, 2010. ArcGIS 10.0. Environmental Systems Research Institute (ESRI), Redlands, CA.

eWater_CRC, 2010. Source Catchments User Guide. eWater Cooperative Research Centre (CRC), Canberra, ACT.

Fabricius, K., Okaji, K., De'ath, G., 2010. Three lines of evidence to link outbreaks of the crown-of-thorns seastar \&lt;i\&gt;Acanthaster planci\&lt;/i\&gt; to the release of larval food limitation. Coral Reefs 29, 593-605.

Fabricius, K.E., 2011. Factors Determining the Resilience of Coral Reefs to Eutrophication: A Review and Conceptual Model

Coral Reefs: An Ecosystem in Transition, in: Dubinsky, Z., Stambler, N. (Eds.). Springer Netherlands, pp. 493-505.

Fernandes, L., Day, J., Lewis, A., Slegers, S., Kerrigan, B., Breen, D., Cameron, D., Jago, B., Hall, J., Lowe, D., Innes, J., Tanzer, J., Chadwick, V., Thompson, L., Gorman, K., Simmons, M., Barnett, B., Sampson, K., De'ath, G., Mapstone, B., Marsh, H., Possingham, H., Ball, I., Ward, T., Dobbs, K., Aumend, J., Slater, D., Stapleton, K., 2005. Establishing representative no-take areas in the Great Barrier Reef: Large-scale implementation of theory on marine protected areas. Conservation Biology 19, 1733-1744.

Gabric, A.J., Bell, P.R.F., 1993. REVIEW OF THE EFFECTS OF NONPOINT NUTRIENT LOADING ON COASTAL ECOSYSTEMS. Australian Journal of Marine and Freshwater Research 44, 261-283.

GBRMPA, 2009. Great Barrier Reef Outlook Report 2009. Great Barrier Reef Marine Park Authority (GBRMPA), Townsville, QLD, p. 212.

Gordon, H.R., Wang, M., 1994. Retrieval of water-leaving radiance and aerosol optical thickness over the oceans with SeaWiFS: a preliminary algorithm. Appl. Opt. 33, 443-452.

Halpern, B.S., Ebert, C., Kappel, C.V., Madin, E.M.P., Micheli, F., Perry, M.T., Selkoe, K.A., Walbridge, S., 2009. Global priority areas for incorporating land-sea connections in marine conservation. Conservation Letters 2, 189-196.

Halpern, B.S., Selkoe, K.A., Micheli, F., Kappel, C.V., 2007. Evaluating and Ranking the Vulnerability of Global Marine Ecosystems to Anthropogenic Threats. Conservation Biology 21, 1301-1315.

Halpern, B.S., Walbridge, S., Selkoe, K.A., Kappel, C.V., Micheli, F., D'Agrosa, C., Bruno, J.F., Casey, K.S., Ebert, C., Fox, H.E., Fujita, R., Heinemann, D., Lenihan, H.S., Madin, E.M.P., Perry, M.T., Selig, E.R., Spalding, M., Steneck, R., Watson, R., 2008. A global map of human impact on marine ecosystems. Science 319, 948-952.

Haynes, D., Brodie, J., Waterhouse, J., Bainbridge, Z., Bass, D., Hart, B., 2007. Assessment of the water quality and ecosystem health of the Great Barrier Reef (Australia): Conceptual models. Environmental Management 40, 993-1003.

Howarth, R.W., 2008. Coastal nitrogen pollution: A review of sources and trends globally and regionally. Harmful Algae 8, 14-20.

Hughes, T., Bellwood, D., Baird, A., Brodie, J., Bruno, J., Pandolfi, J., 2011. Shifting base-lines, declining coral cover, and the erosion of reef resilience: comment on Sweatman et al. (2011). Coral Reefs 30, 653-660.

Hutchings, P., Haynes, D., Goudkamp, K., McCook, L., 2005. Catchment to Reef: Water quality issues in the Great Barrier Reef Region An overview of papers. Marine Pollution Bulletin 51, 3-8.

Joo, M., Raymond, M., McNeil, V., Huggins, R., Turner, R., Choy, S., 2012. Estimates of sediment and nutrient loads in ten major catchments draining to the Great Barrier Reef during 2006-2009. Marine Pollution Bulletin In Press.

Kennedy, K., Schroeder, T., Shaw, M., Haynes, D., Lewis, S., Bentley, C., Paxman, C., Carter, S., Brando, V., Bartkow, M., Hearn, L., Mueller, J.F., 2012. Long term monitoring of photosystem II herbicides - Correlation with remotely sensed freshwater extent to monitor changes in the quality of water entering the Great Barrier Reef, Australia. Marine Pollution Bulletin In Press.

Klein, C.J., Ban, N.C., Halpern, B.S., Beger, M., Game, E.T., Grantham, H.S., Green, A., Klein, T.J., Kininmonth, S., Treml, E., Wilson, K., Possingham, H.P., 2010. Prioritizing land and sea conservation investments to protect coral reefs. PLoS ONE 5, e12431.

Kleypas, J.A., 1996. Coral reef development under naturally turbid conditions: fringing reefs near Broad Sound, Australia. Coral Reefs 15, 153-167.

Kroon, F.J., Kuhnert, P.M., Henderson, B.L., Wilkinson, S.N., Kinsey-Henderson, A., Abbott, B., Brodie, J.E., Turner, R.D.R., 2012. River loads of suspended solids, nitrogen, phosphorus and herbicides delivered to the Great Barrier Reef lagoon. Marine Pollution Bulletin In Press.

Larcombe, P., Ridd, P.V., Prytz, A., Wilson, B., 1995. Factors controlling suspended sediment on inner-shelf coral reefs, Townsville, Australia. Coral Reefs 14, 163-171. 
Lee, Z.P., Carder, K.L., Arnone, R.A., 2002. Deriving inherent optical properties from water color: a multiband quasi-analytical algorithm for optically deep waters. Appl. Opt. 41, 5755-5772.

Lewis, S., Brodie, J., Ledee, E., Alewijnse, M., 2006. The spatial extent of delivery of terrestrial materials from the Burdekin region in the Great Barrier Reef lagoon, ACTFR Report Australian Centre for Tropical Freshwater Research (ACTFR), James Cook University, Townsville, QLD.

Lewis, S.E., Brodie, J.E., Bainbridge, Z.T., Rohde, K.W., Davis, A.M., Masters, B.L., Maughan, M., Devlin, M.J., Mueller, J.F., Schaffelke, B., 2009. Herbicides: A new threat to the Great Barrier Reef. Environ. Pollut. 157, 2470-2484.

Lubchenco, J., Palumbi, S.R., Gaines, S.D., Andelman, S., 2003. Plugging a hole in the ocean: The emerging science of marine reserves. Ecological Applications 13, 3-7.

Maughan, M., Brodie, J., 2009. Reef exposure to river-borne contaminants: a spatial model. Marine and Freshwater Research 60, 1132-1140.

McCook, L., Ayling, T., Cappo, M., Choat, J., Evans, R., De Freitas, D., Heupel, M., Hughes, T., Jones, G., Mapstone, B., Marsh, H., Mills, M., Molloy, F., Pitcher, C., Pressey, R., Russ, G., Sutton, S., Sweatman, H., Tobin, R., Wachenfeld, D., Williamson, D., 2010. Adaptive management of the Great Barrier Reef: A globally significant demonstration of the benefits of networks of marine reserves. Proc. Natl. Acad. Sci. U. S. A.

McKenzie, L., Collier, C.J., Waycott, M., 2012. Reef Rescue Marine Monitoring Program: Nearshore Seagrass, Annual Report for the sampling period 1st July 2010-31st May 2011. Fisheries Queensland, Cairns, QLD, p. 177.

McKenzie, L., Unsworth, R., 2011. Surving the flood; How long can seagrass “hold it's breath"?, in: McKenzie, L., Yoshida, R.L., Unsworth, R. (Eds.), Seagrass-Watch News. Seagrass-Watch HQ, p. 28.

McKenzie, L., Unsworth, R., Waycott, M., 2010. Reef Rescue Marine Monitoring Program: Intertidal Seagrass, Annual Report for the sampling period 1st September 2009 - 31st May 2010. Fisheries Queensland, Cairns, QLD, p. 136.

MEA, 2005. Millennium Ecosystem Assessment - Ecosystems and Human Well-being: Biodiversity Synthesis. World Resources Institute, Washington, D.C.

Morichon, D., Dailloux, D., Aarninkhof, S., Abadie, S., 2008. Using a Shore-Based Video System to Hourly Monitor Storm Water Plumes (Adour River, Bay of Biscay). J. Coast. Res., 133-140.

Ohde, T., Siegel, H., 2001. Correction of bottom influence in ocean colour satellite images of shallow water areas of the Baltic Sea. International Journal of Remote Sensing 22, 297-313.

Okada, Y., Mukai, S., Sano, I., 2003. Modified cloud flag for SeaWiFS data over turbid water regions. Geophys. Res. Lett. $30,1193$.

Orpin, A.R., Ridd, P.V., Stewart, L.K., 1999. Assessment of the relative importance of major sediment transport mechanisms in the central Great Barrier Reef lagoon. Australian Journal of Earth Sciences 46, 883-896.

Qin, Y., Brando, V.E., Dekker, A.G., Blondeau-Patissier, D., 2007. Validity of SeaDAS water constituents retrieval algorithms in Australian tropical coastal waters. Geophys. Res. Lett. 34, L21603.

Reid, D.J., Chiaroni, L.D., Hewitt, J.E., Lohrer, D.M., Matthaei, C.D., Phillips, N.R., Scarsbrook, M.R., Smith, B.J., Thrush, S.F., Townsend, C.R., van Houte-Howes, K.S.S., Wright-Stow, A.E., 2011. Sedimentation effects on the benthos of streams and estuaries: a crossecosystem comparison. Marine and Freshwater Research 62, 1201-1213.

Roberts, J.J., Best, B.D., Dunn, D.C., Treml, E.A., Halpin, P.N., 2010. Marine Geospatial Ecology Tools: An integrated framework for ecological geoprocessing with ArcGIS, Python, R, MATLAB, and C++. Environmental Modelling \&amp; Software 25, $1197-1207$.

Salisbury, J.E., Campbell, J.W., Linder, E., David Meeker, L., Müller-Karger, F.E., Vörösmarty, C.J., 2004. On the seasonal correlation of surface particle fields with wind stress and Mississippi discharge in the northern Gulf of Mexico. Deep Sea Research Part II: Topical Studies in Oceanography 51, 1187-1203.

Schroeder, T., Devlin, M., Brando, V., Dekker, A., Brodie, J., Clementson, L., McKinna, L.I., 2012. Inter-annual variabiliyt of wet season freshwater plume extent into the Great Barrier Reef lagoon based on satellite coastal ocean colour observations. Marine Pollution Bulletin In Press.

Stoms, D.M., Davis, F.W., Andelman, S.J., Carr, M.H., Gaines, S.D., Halpern, B.S., Hoenicke, R., Leibowitz, S.G., Leydecker, A., Madin, E.M.P., Tallis, H., Warner, R.R., 2005. Integrated coastal reserve planning: making the land-sea connection. Frontiers in Ecology and the Environment 3, 429-436.

Sweatman, H., Delean, S., Syms, C., 2011. Assessing loss of coral cover on Australia's Great Barrier Reef over two decades, with implications for longer-term trends. Coral Reefs 30, 521-531.

Tallis, H., Ferdana, Z., Gray, E., 2008. Linking terrestrial and marine conservation planning and threats analysis. Conservation Biology 22, 120-130.

Thomas, A.C., Weatherbee, R.A., 2006. Satellite-measured temporal variability of the Columbia River plume. Remote Sensing of Environment 100, 167-178.

Thrush, S.F., Hewitt, J.E., Cummings, V.J., Ellis, J.I., Hatton, C., Lohrer, A., Norkko, A., 2004. Muddy waters: elevating sediment input to coastal and estuarine habitats. Frontiers in Ecology and the Environment 2, 299-306.

UNEP, 2012. 21 Issues for the 21st Century: Result of the UNEP Foresight Process on Emerging Environmental Issues, in: Alcamo, J., Leonard, S.A. (Eds.). United Nations Environment Programme (UNEP), Nairobi, Kenya, p. 56.

Walling, D.E., 2006. Human impact on land-ocean sediment transfer by the world's rivers. Geomorphology 79, $192-216$. 
Wang, M., Shi, W., 2007. The NIR-SWIR combined atmospheric correction approach for MODIS ocean color data processing. Optics Express 15, 15722-15733.

Waterhouse, J., Brodie, J., Lewis, S., Mitchell, A., 2012. Quantifying the sources of pollutants to the Great Barrier Reef. Marine Pollution Bulletin In Press.

Waycott, M., Longstaff, B.J., Mellors, J., 2005. Seagrass population dynamics and water quality in the Great Barrier Reef region: A review and future research directions. Marine Pollution Bulletin 51, 343-350.

Wilkinson, S., Henderson, A., Chen, Y., Sherman, B., 2004. SedNet user guide, Version 2, Client Report, CSIRO Land and Water. CSIRO Land and Water, Canberra, ACT.

Wilson, K., Pressey, R.L., Newton, A., Burgman, M., Possingham, H., Weston, C., 2005. Measuring and incorporating vulnerability into conservation planning. Environmental Management 35, 527-543.

Wooldridge, S.A., 2009. Water quality and coral bleaching thresholds: Formalising the linkage for the inshore reefs of the Great Barrier Reef, Australia. Marine Pollution Bulletin 58, 745-751.

Worm, B., Barbier, E.B., Beaumont, N., Duffy, J.E., Folke, C., Halpern, B.S., Jackson, J.B.C., Lotze, H.K., Micheli, F., Palumbi, S.R., Sala, E., Selkoe, K.A., Stachowicz, J.J., Watson, R., 2006. Impacts of biodiversity loss on ocean ecosystem services. Science 314, 787-790. 